(6) Regenerative Medicine

Regen. Med. 7(3), Suppl. 1 (2012)

Cell Therapy and Regenerative Medicine Glossary; PAS 84:2012

S6 FOREWORD

S10 PREFACE

S12 INTRODUCTION

S14 SCOPE

S15 TERMS \& DEFINITIONS

S90 ANNEX A (INFORMATIVE)

REGULATORY TERMS

S97 ANNEX B (INFORMATIVE)

FINANCE

S100 BIBLIOGRAPHY

S111 INDEX 


\section{Publishing and copyright information}

The BSI copyright notice displayed in this document indicates when the document was last issued.

(C) The British Standards Institution 2012. Published by BSI Standards Limited 2012.

ISBN 9780580749049

ICS $01.040 .11 ; 11.020$

No copying without BSI permission except as permitted by copyright law.

\section{Publication history}

First published April 2008

Second Edition published March 2012 


\section{Regenerative Medicine}

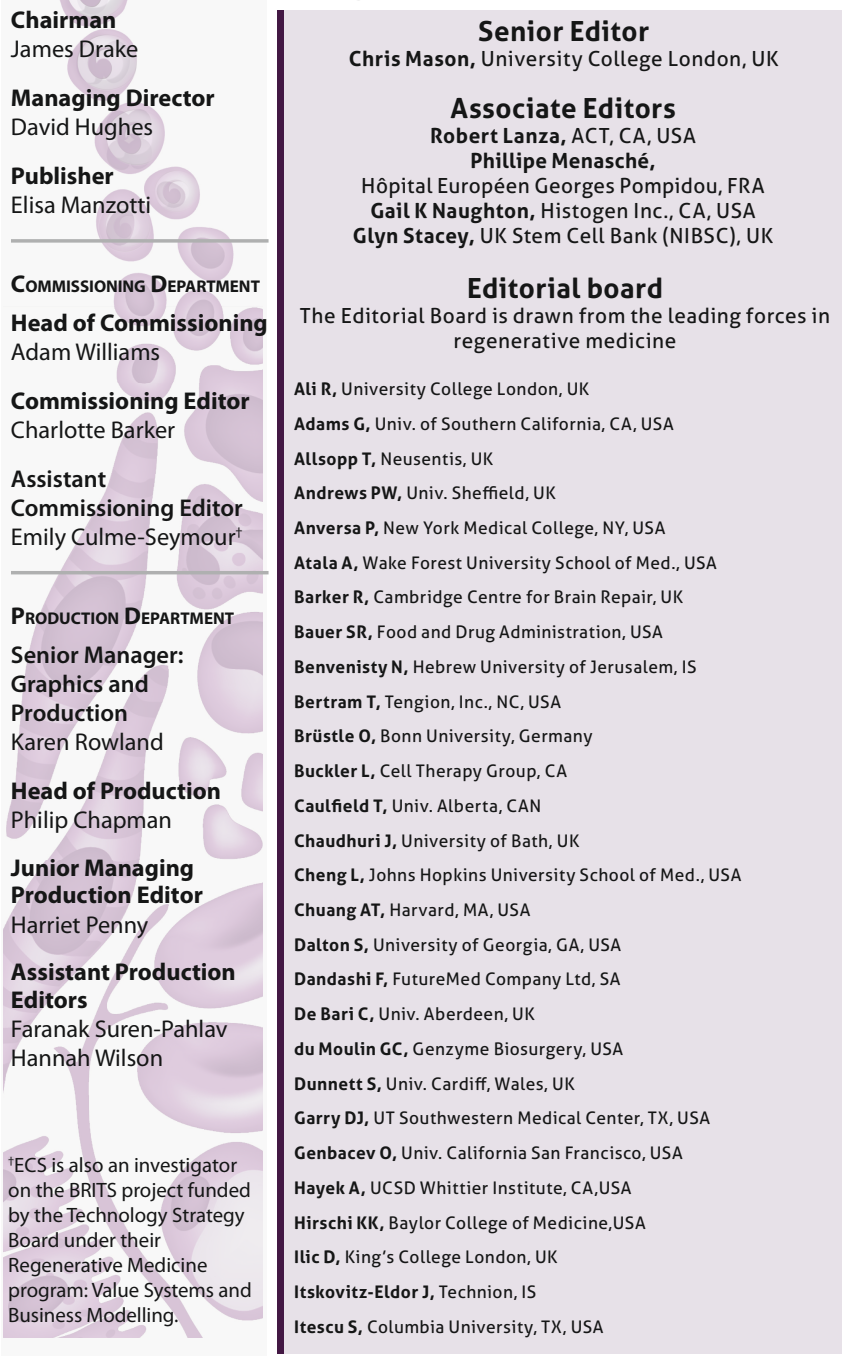

Advertising Enquiries

Sarah Bishop, Business Development Executive

s.bishop@futuremedicine.com

Editorial Enquiries

Elisa Manzotti, Publisher

e.manzotti@futuremedicine.com

Subscription Enquiries

info@futuremedicine.com

Reprint Enquiries

Sam Cavana, Reprint Sales Manager

s.cavana@futuremedicine.com

Permissions Enquiries

Leela Ription, Permissions Coordinator

I.ripton@futuremedicine.com

\section{Indexing:}

Medline/Index Medicus, Science Citation Index Expanded, Biotechnology Citation Index ${ }^{\oplus}$, Journal Citation Reports, Biological Abstracts, BIOSIS Previews, EMBASE/ Excerpta Medica, Chemical Abstracts

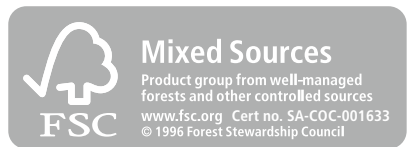

www.futuremedicine.com 


\section{Editorial board (cont.).}

The Editorial Board is drawn from the leading forces in regenerative medicine

Jorgensen C, Lapeyronie Hospital, FR

Kaplan B, Ben's Stem Cell News, USA

Keirstead HS, Reeve-Irvine Research Center.

CA, USA

Kemp P, Intercytex, UK

Kloner R, Good Samaritan Hospital (USC), USA

Koliatsos V, Johns Hopkins Uni. School of Med., USA

Krtolica A, StemLifeLine, Inc., CA, USA

Lako M, Univ. Newcastle, UK

Lawford Davies J, Lawford Davies Denoon, UK

Laurencin C, MIT, MA, USA

Lebkowski JS, USA

Lewis A, USA

L'Heureux N, Cytograft, USA

Li R-K, Toronto General Hospital, CAN

MacKay G, Organogenesis, MA, USA

Madeddu P, Bristol Heart Institute, UK

Martino G, San Raffaele Hospital, Italy

McNeish JD, GlaxoSmithKline, USA

Miller RH, Case School of Medicine Cleveland, $\mathrm{OH}$, USA

Oreffo R, Univ. Southampton, UK

Patel A, McGowan Inst. for Regenerative Med., USA

Penn MS, Cleveland Clinic Foundation, $\mathrm{OH}$, USA
Polak JM, Imperial College London, UK

Rao M, National Institutes for Health, USA

Rowley JA, Lonza Cell Therapy, MD, USA

Russell AJ, Carnegie Mellon, USA

Sachlos E, McMaster Univ, CAN

Salter B, King's College London, UK

Sanberg P, USF Coll. of Med., FL, USA

Scharfmann R, INSERM, FR

Sharpe P, King's College, London, UK

Siegel B, Genetics Policy Institute

Sipp D, RIKEN, JP

Snyder EY, The Burnham Institute, USA

Soria B, Andalusian Ctr Mol Biol and Regen Med, Spain

Surani A, University of Cambridge, UK

Sussman M, SDSU Heart Institute, CA, USA

Terzic A, Mayo Clinic, MN, USA

Trounson A, CIRM, USA

Waldman SA, Thomas Jefferson University, PA, USA

West M, BioTime, CA, USA

Wilson IA, GE Healthcare Medical Diagnostics, UK

Yoon Y-S, Tufts University School of Med., USA

Young L, University of Nottingham, UK

Disclaimer: Whilst every effort is made by the Publisher and Editorial Board to ensure that no inaccurate or misleading data, opinions or statements appear in this journal, they wish to make it clear that the data and opinions appearing herein are the responsibility of the contributor concerned. Accordingly, the Publisher, Editorial Board and their respective employees, officers and agents accept no liability whatsoever for the consequences of any inaccurate or misleading data, opinions or statements.

Copyright: Conditions of sale: Regenerative Medicine may be circulated only to those members of staff who are employed at the site at which the subscription is taken out. Readers are reminded that, under internationally agreed copyright legislation, photocopying of copyright materials is prohibited other than on a limited basis for personal use. Thus making copies of any article published in Regenerative Medicine is a breach of the law and can be prosecuted.

\section{Future $"$ fo
Medicine
part of}


This glossary has been produced in partnership with:
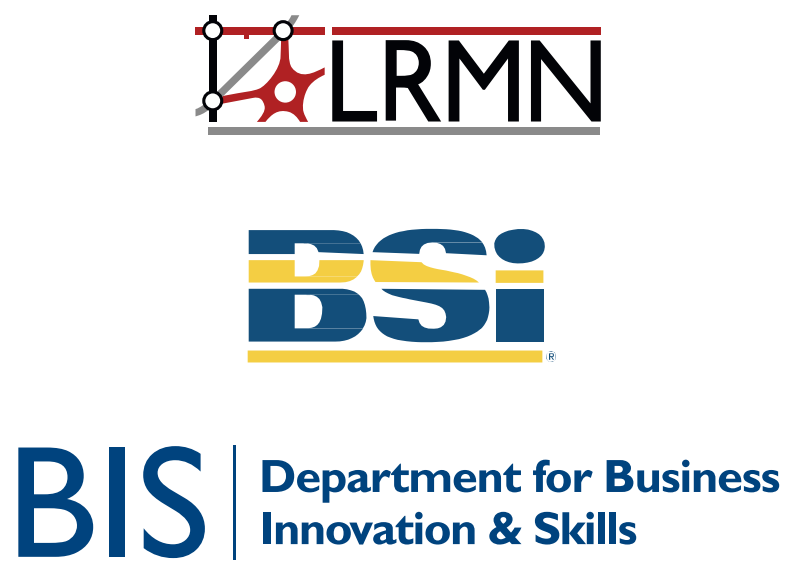

\section{(6) Regenerative Medicine}

Toward cellular solutions for human health and well being

Future Medicine Ltd Unitec House 2 Albert Place London, N3 10,B, UK

\section{Editorial}

Tel.: +44 (0)20 83716090

Fax: +44 (0)20 83432313

\section{Customer Services}

Tel.: +44(0)20 83716080

Fax: $+44(0) 2083716099$

Email:info@futuremedicine.com www.futuremedicine.com 


\section{FOREWORD}

This Publicly Available Specification (PAS) was commissioned by the UK Department for Business, Innovation and Skills (BIS). Its development was facilitated by BSI Standards Limited and published under licence from The British Standards Institution. It came into effect on 30 March 2012.

Acknowledgement is given to the technical author, Emily Culme-Seymour, and the following organizations that were involved in the development of this vocabulary as members of the Steering Group:

- Anthony Nolan (Alejandro Madrigal)

- CellData Services (Alison Wilson)

- Consulting on advanced biologicals (Christopher Bravery)

- Department for Business, Innovation and Skills (Michael Skwarek and Sitali Simwami)

- LGC (Julian Braybrook)

London Regenerative Medicine Network (Emily CulmeSeymour)

- National Institute for Biological Standards and Control (Glyn Stacey)

- National Physical Laboratory (Max Ryadnov)

- University College London (Chris Mason)

* University of Oxford (Paul Fairchild)

Acknowledgement is also given to those organizations and individuals that submitted comments during the public consultation.

The British Standards Institution retains ownership and copyright of this PAS. BSI Standards Limited as the publisher of the PAS reserves the right to withdraw or amend this PAS on receipt of authoritative advice that it is appropriate to do so. This PAS will be reviewed at intervals not exceeding two years, and any amendments arising from the review will be published as an amended PAS and publicized in Update Standards. 
This PAS is not to be regarded as a British Standard. It will be withdrawn upon publication of its content in, or as, a British Standard.

The PAS process enables a specification to be rapidly developed in order to fulfil an immediate need in industry. A PAS may be considered for further development as a British Standard, or constitute part of the UK input into the development of a European or International Standard.

\section{Supersession}

This PAS supersedes PAS 84:2008, which is withdrawn.

\section{Information about this document}

This is a full revision of the PAS and introduces the following principal changes:

- Update of existing terms and definitions for accuracy and relevance

- Addition of new terms that have appeared within the research, clinical, bioprocessing and regulatory space since the last revision

Update of the annex on regulatory terms to reflect changes in legislation and include regulatory terms used in the USA as well as in the UK and Europe

- Addition of an annex on finance terms that are likely to be of use to the cell therapy and regenerative medicine community

\section{Relationship with other publications}

This PAS provides a set of terms and definitions that is of relevance to the cell therapy and regenerative medicine industry. It includes definitions of terms used in:

PAS 83, Developing human cells for clinical applications in the European Union and the United States of America - Guide 
- PAS 93, Characterization of human cells for clinical applications - Guide

Where possible, an attempt has been made to use terms and definitions that have been defined in existing standards, in particular ASTM F2312-11, Standard terminology relating to tissue engineered medical products.

A number of regulations exist that are relevant to the field of cell therapy and regenerative medicine. These regulations contain terms that are defined in some detail. In some instances regulatory definitions have been included verbatim. However, in order for this PAS to achieve its intended objective, more succinct and precise definitions consistent with regulations have been developed.

\section{Presentational conventions}

The terms and definition in the PAS are presented in roman (i.e. upright) type.

Commentary, explanation and general informative material is presented in smaller italic type.

When terms defined in this PAS are used in the definition or notes of another term, they are shown in bold type.

Where a term has been given a meaning narrower than its generally accepted meaning, a qualification has been included in angular brackets at the start of the definition denoting the context within which it has been defined, i.e. <...>.

Spelling conforms to The Shorter Oxford English Dictionary. If a word has more than one spelling, the first spelling in the dictionary is used.

\section{Feedback}

Feedback on the technical content of this PAS can be submitted through the BSI Document Feedback system http://feedback.bsigroup.com.

Any feedback received will be reviewed when developing future revisions of this document.

\section{Contractual \& legal considerations}

Attention is drawn to the following statutory regulations. 
European Directive 2001/83/EC relating to medicinal products for human use (and amendments) [1]

- European Directive 2004/23/EC on setting standards of quality and safety for the donation, procurement, testing, processing, preservation, storage and distribution of human tissues and cells [2] implemented in the UK by Human Tissue (Quality and Safety for Human Application) Regulations 2007 [3]

- European Directive 2010/45/EU on standards of quality and safety of human organs intended for transplantation [4]

- European Regulation No. 1394/2007 on advanced therapy medicinal products [5]

- Human Fertilisation and Embryology Act 1990 (and amendments) [6]

- Human Tissue Act 2004 [7]

Human Tissue (Scotland) Act 2006 (and amendments) [8]

This publication does not purport to include all the necessary provisions of a contract. Users are responsible for its correct application.

Compliance with a PAS cannot confer immunity from legal obligations. 


\section{PREFACE}

The first edition of this popular glossary was published in 2008. Over the past 4 years, a great many new terms have appeared. These additions reflect the rapid development of regenerative medicine, including the spinning out of cell therapy as a dominant new therapeutic modality. It is encouraging that the glossary's name has thus been modified in order to reflect the step-change importance of cell therapy, whilst continuing to recognize its linkages with regenerative medicine.

Regenerative medicine, the pursuit of regeneration by drugs, biomaterials, devices and/or cells, originated in the 1980 s and today is an expanding multibillion pound industry. Likewise, the emerging cell therapy industry is predicted to grow from $£ 1$ billion in global revenue in 2011 to over $£ 3$ billion by 2014, with even greater growth expected to follow. These projections will not be achieved unless certain barriers are removed. There is an imperative for all stakeholders - patients, researchers, clinicians, entrepreneurs, manufacturers, press, public and politicians, to share a common language. This signals an urgent need for a universally agreed set of terms and definitions.

The first edition of this glossary started to facilitate this process and has admirably demonstrated its utility in the academic, clinical, business and societal settings. Indeed the demand for the original glossary led to tens of thousands of PDF web downloads, as well as a number of publisher reprints. Given the rapid scientific and technical progress since 2008, it is now time for a new and up to date edition to maintain the breadth and accuracy of the terms in use today.

As a globally acknowledged leader in cell therapy and regenerative medicine, and the pioneer of standardization through The British Standards Institution, the UK is well placed to take responsibility for maintaining this comprehensive glossary. Regularly updating the glossary to accommodate the pace of progress will help to ensure that language is not a barrier to successful clinical translation and commercialization. 
As a robust supporter of research, translation and commercialization of cell therapies and regenerative medicine, I would like to warmly congratulate the steering group of international experts responsible for producing this second edition - one sponsored by the UK Government, but intended for global use.

Rt Hon David Willetts MP Minister of State for Universities and Science Department for Business, Innovation \& Skills 


\section{INTRODUCTION}

This PAS has been developed to encourage the use of common terms and definitions within the field of cell therapies and regenerative medicine. For the purpose of this PAS:

- Cell therapy is a "therapy in which cells are administered to the body to the benefit of the recipient"; and

- Regenerative medicine is a "process for replacing or regenerating cells, tissues or organs, to restore or establish normal function".

There has been increasing scrutiny of current standardization and regulations by researchers, manufacturers and the general public as cell therapy products and regenerative medicine products move nearer to commercialization.

UK stakeholders identified a need for standardization to achieve consensus on the terms and definitions used within cell therapies and regenerative medicine. Using the views and opinions of key UK stakeholders, this PAS has been developed to meet this need. The first edition of PAS 84 was published in 2008 and since then a number of developments have taken place in this field. As such, this revision of PAS 84 has been conducted to introduce changes that reflect these developments.

The aim of this PAS is to provide clear guidance on the meaning of terminology currently used within this field in the UK by industry, regulators, government and academia. Where applicable, terms and definitions have been aligned with existing regulations, codes of practice or standards. The sources of reproduced or adapted terms and definitions are referenced within this PAS.

It is recognized that there are international differences in terminology in current use, such as between the USA and Europe and particularly with regard to regional legislation. In this case, the European legislative or common terms have been used where possible. 
It is intended that this document will help UK stakeholders to:

- Prepare for legal, commercial and societal issues;

- Facilitate a common understanding of the science of cell therapies and regenerative medicine;

- Improve communication and understanding of advances in the field;

Demonstrate best practice and product quality; and

Reduce research, development, production and transaction costs. 


\section{SCOPE}

This PAS lists terms and definitions:

- Associated with the naming of types of cell therapy and regenerative medicine products; and

- That describe materials, processes, methodologies and applications within cell therapies and regenerative medicine.

It covers:

General terms;

- Cell and tissue components;

- Non-cellular components;

- Cell and tissue procurement;

" Measurement and analysis;

- Manufacturing and production; and

- Clinical trials.

Alternative definitions of terms found in regulations relevant to the cell therapy and regenerative medicine industry are covered in Annex A.

Finance terms and definitions relevant to the cell therapy and regenerative medicine industry are covered in Annex B. 


\section{TERMS \& DEFINITIONS}

\section{1 acceptance criteria}

predetermined criteria for acceptance of a test result NOTE Such criteria can include numerical limits and ranges.

[derived from the European Commission's Eudralex: The Rules Governing Medicinal Products in the European Union, Volume 4, Part II [9]]

\section{2 active implantable medical device}

active medical device which is intended to be totally or partially introduced, surgically or medically, into the human body or by medical intervention into a natural orifice, and which is intended to remain after the procedure

[European Directive 90/385/EEC (and amendments) [10]]

\section{2.3 active medical device}

medical device relying for its functioning on a source of electrical energy or any source of power other than that directly generated by the human body or gravity

[European Directive 90/385/EEC (and amendments) [10]] 


\section{- 2.4 active substance}

substance or mixture of substances intended to be used in the manufacture of a medicinal product and that, when used in the production of a medicinal product, becomes a part of the medicinal product that furnishes pharmacological activity or other direct effect in the diagnosis, cure, mitigation, treatment or prevention of disease or affects the structure and function of the body

NOTE I Also known as active pharmaceutical ingredient (API) and drug substance.

NOTE 2 See also cellular active substance.

[derived from ICH Harmonised Tripartite Guideline Q7 [11]]

\section{5 active surveillance}

surveillance ascertaining the number of adverse events via a continuous pre-organized process

NOTE Examples include the follow-up of patients treated with a particular medicinal product through a risk management programme. In general, it is more feasible to obtain comprehensive data on individual adverse events through active surveillance than through passive surveillance.

[derived from the European Commission's Eudralex: The Rules Governing Medicinal Products in the European Union, Volume 9A [12]] 


\section{6 admixed embryo}

embryo that contains both human and animal material

NOTE I Also known as hybrid embryo.

NOTE 2 Examples include an animal chimera embryo, a cytoplasmic hybrid embryo (cybrid) a human chimera embryo and a transgenic human embryo.

NOTE 3 A legal definition of human admixed embryo applicable in the UK is given in Table A.1.

NOTE 4 See also permitted embryo

I 2.7 adult stem cell

stem cell derived from an adult body or fetus

NOTE Also known as somatic stem cell or stromal stem cell.

[derived from the UK Stem Cell Bank's Code of Practice for the Use of Human Stem Cell Lines [13]]

- 2.8 advanced therapy medicinal product

medicinal product for human use that is a gene therapy medicinal product, a somatic cell therapy medicinal product or tissue engineered product

[European Regulation No. 1394/2007 [5]

\section{I.9 adventitious}

coming from an external source

\section{2.10 adventitious agent}

unintentionally introduced infectious contaminant

[derived from ASTM F2312-11] 


\section{2.11 adverse event}

unexpected occurrence that might have an influence on a patient or clinical trial subject who has been administered a medicinal product, and that is not necessarily caused by the product

NOTE I A legal definition applicable in the EU for clinical trials is given in Table A.1.

NOTE 2 Also known as adverse experience. A legal definition of adverse experience applicable in the USA is given in Table A.1.

NOTE 3 See also serious adverse event (SAE).

\section{2.12 adverse event reporting}

system for notification to an authority of adverse events

NOTE Notification can be made to national regulatory authorities as well as international authorities such as the World Health Organization (WHO).

\subsection{3 adverse reaction}

response to a medicinal product which is noxious and unintended

NOTE I Two legal definitions applicable in the EU are given in Table A.1, the first relating to clinical trials and the second relating to medicinal products for human use.

NOTE 2 See also serious adverse reaction (SAR) and unexpected adverse reaction (UAR). 


\subsection{4 allogeneic}

where donor and recipient are different individuals

\subsection{5 allograft}

\section{allogeneic graft}

NOTE Also known as homograft.

\section{- 2.16 ancillary material}

components used during the manufacture of a medicinal product that are not deliberately present in the medicinal product

NOTE Examples include cytokines, growth factors, monoclonal antibodies, cell-separation devices and media components.

\subsection{7 animal chimera embryo}

admixed embryo created by inserting human cells into an animal embryo

[derived from the Human Fertilisation and Embryology

Authority's report on hybrids and chimeras [14]]

\subsection{8 apoptosis}

programmed cell death

NOTE See also necrosis.

\subsection{9 arm}

treatment or patient group in a randomized trial 


\subsection{0 aseptic technique}

manner of handling or processing where the risk of contamination with living or dead bacteria, fungi or viruses and other biological agents is minimized or prevented

\section{- 2.21 asymmetric cell division}

cell division where each daughter cell has a different cellular fate

\subsection{2 audit}

documented, systematic evaluation to determine whether approved policies, standard operating procedures or operations have been properly implemented and are being followed

[NetCord-FACT's International Standards for Cord Blood collection, Processing, and Release for Administration [15]]

\subsection{3 autograft}

autologous graft

\subsection{4 autologous}

where donor and recipient are the same individual

2.25 baseline

information gathered at the beginning of a study from which variations found in the study are measured 


\section{2.26 batch (or lot)}

defined quantity of starting material, packaging material or product processed in one process or series of processes so that it could be expected to be homogeneous

NOTE To complete certain manufacturing steps,

it may be necessary to divide a batch into

a number of sub-batches, which are later

brought together to form a final homogene-

ous batch. In the case of continuous manu-

facture, the batch corresponds to a defined

fraction of the production, characterized by

its intended homogeneity.

[derived from the European Commission's Eudralex: The Rules Governing Medicinal Products in the European Union, Volume 4, Glossary [16]]

\section{2.27 batch (or lot) number}

unique combination of numbers, letters and/or symbols that identifies a batch (or lot) and from which the production and distribution history can be determined

[European Commission's Eudralex: The Rules Governing Medicinal Products in the European Union, Volume 4, Glossary [16]]

I 2.28 bioactive agent agent that has a biological effect on cells or tissue

\section{2.29 bioaesthetics}

regenerative medicine-like therapies aimed at cosmesis rather than traditional medical alignments 


\section{I.30 bioburden}

quantity and type of microorganisms present in a raw material, intermediate or active substance NOTE Bioburden is considered contamination when the quantity of microorganisms has exceeded an accepted level or the microorganisms detected are of an objectionable type.

[derived from the European Commission's Eudralex: The Rules Governing Medicinal Products in the European Union, Volume 4, Part II [9]]

\subsection{1 biocompatibility}

ability of a material to perform with an appropriate host response in a specific application

[The Williams Dictionary of Biomaterials [17]]

\subsection{2 biodistribution}

dispersal of biological agents or medicinal products throughout a human or animal body

\section{- 2.33 biological agent}

microorganism, cell culture or human endoparasite, whether or not genetically modified, which can cause infection, allergy, toxicity or otherwise create a hazard to human health

[The Control of Substances Hazardous to Health Regulations $2002[\mathbf{1 8}]]$

\section{2.34 biological medicinal product}

product, the active substance of which is a biological substance

NOTE Also known as biologic.

[European Directive 2001/83/EC (and amendments) [1] 


\section{2.35 biological substance}

substance that is produced by or extracted from a biological source and that needs, for its characterization and the determination of its quality, a combination of physicochemical-biological testing together with the production process and its control

[European Directive 2001/83/EC (and amendments) [1]]

\subsection{6 biomarker}

molecular indicator of a specific biological property

\subsection{7 biomaterial}

material intended to interface with biological systems to evaluate, treat, augment or replace any tissue, organ or function of the body

[BS EN ISO 10993-6:2009, 3.3]

\subsection{8 biomolecule}

biologically active peptide, protein, carbohydrate, vitamin, lipid or nucleic acid produced by and purified from naturally occurring or recombinant organisms, tissues or cell lines or synthetic analogs of such molecules

[ASTM F2312-11]

\subsection{9 bioprocessing}

activity performed on cells, tissues and organs other than collection

NOTE For example, preparation and preservation for storage and packaging. 


\section{2.40 bioreactor}

device, equipment or apparatus designed to contain structures, both cellular and molecular, that are capable of taking part in a specific biological process and from which the products of the process can be harvested or extracted

[The Williams Dictionary of Biomaterials [17]]

\subsection{1 biosimilar}

new biological medicinal product claimed to be similar in terms of quality, safety and efficacy to a reference medicinal product that has been granted a marketing authorization in the community

NOTE Also known as similar biological medicinal product.

[derived from the definition of similar biological medicinal product in the European Medicines Agency's Guideline on similar biological medicinal products containing biotechnology-derived proteins as active substance: Quality issues [19]]

\subsection{2 blastocyst}

pre-implantation embryo of about 150 cells produced by cell division around 144 hours following fertilization

NOTE I The blastocyst is a sphere made up of an outer layer of cells (the trophoblast) and the inner cell mass.

NOTE 2 See also morula

[derived from the Stem Cell Information Glossary [20]]

\subsection{3 blastomere}

cell contained within a morula 


\section{2.44 cancer vaccine}

therapy intended to stimulate a primary immune response to tumour-associated antigens, with the intention of inducing tumour regression

NOTE Also known as cancer immunotherapy.

\section{2.45 cell authenticity}

degree to which a population of cells has the correct identity and is free of other cell types

NOTE The quality of the authentication depends on the specificity and sensitivity of the technique used.

\section{2.46 cell bank}

collection of cells of uniform composition stored under defined conditions

NOTE I Uniform composition refers to the collection of cells being representative of the original cell culture or cultures from which they are derived.

NOTE 2 A two-tiered cell banking system consisting of a master cell bank (MCB) and working cell bank (WCB) is commonly used for cell lines that are to be used extensively within a process.

[derived from ICH Harmonised Tripartite Guideline O-5D [21] 


\section{2.47 cell-based medicinal product (CBMP)}

medicinal product containing cells

NOTE These products may be combined with non-cellular components and may include genetically modified human cells.

[derived from the European Medicines Agency's Guideline on Human Cell-Based Medicinal Products [22]]

\section{2.48 cell culture}

in vitro growth and maintenance of cells

\section{| 2.49 cell division}

process by which a cell divides to form daughter cells NOTE See also asymmetric cell division.

\subsection{0 cell expansion}

increase in the number of cells by their proliferation

\section{2.51 cell line}

characterized cell culture that has been demonstrated to be phenotypically and genotypically consistent over a specified number of population doublings

2.52 cell migration

movement of cells in response to a stimulus

\subsection{3 cell morphology}

microscopic study of the form and structure of cells 


\section{2.54 cell selection}

separation of a homogenous population of cells from a heterogeneous population

\section{2.55 cell surface marker}

biomolecule expressed on the surface of a cell and is used to identify cell type

\section{2.56 cell therapy}

therapy in which cells are administered to the body to the benefit of the recipient

\section{2.57 cell therapy product} product consisting of cells used for cell therapy

\subsection{8 cell viability}

measure of a cell's potential for metabolism or multiplication

I 2.59 cellular active substance active substance that consists of cells and/or tissue

I 2.60 cellular starting material starting material that consists of cells and/or tissue 


\section{2.61 centralized authorization procedure} procedure leading to a marketing authorization

NOTE I This procedure is administered by the European Medicines Agency (EMA) in accordance with European Regulation No. 726/2004 [23]. The procedure is mandatory for certain medicinal products, including all advanced therapy medicinal products (ATMPs).

NOTE 2 Also known as centralized procedure.

\subsection{2 chief investigator}

investigator who takes overall charge of a multicentre study

NOTE See also clinical investigator and principal investigator.

I 2.63 chimera

organism consisting of two or more tissues of different genetic composition

NOTE Conventionally produced by the injection of embryonic stem cells into a recipient blastocyst or in adults following haematopoietic stem cell transplantation.

I 2.64 chimerism

condition of being a chimera 


\section{2.65 cleanroom (or clean facility)}

room in which the concentration of airborne particles is controlled, and which is constructed and used in a manner to minimize the introduction, generation, and retention of particles inside the room, and in which other relevant parameters, e.g. temperature, humidity, and pressure, are controlled as necessary

[BS EN ISO 14644-1:1999, 2.1.1]

\subsection{6 clinical equivalent}

medicinal product that contains essentially an identical amount of an identical active substance to that found in another medicinal product, and that provides an identical therapeutic effect to that other medicinal product

NOTE I A decision on whether a therapeutic effect is considered identical to another therapeutic effect is determined by assessing the extent to which a symptom or disease is controlled by the medicinal product.

NOTE 2 Also known as therapeutic equivalent.

\subsection{7 clinical follow-up}

follow-up of patients conducted by a healthcare professional

NOTE I It includes prevention, screening, monitoring, diagnosis and treatment of diseases, injuries, complications, adverse reactions and medical errors.

NOTE 2 See also post-market surveillance.

[European Medicines Agency's Guideline on safety and efficacy follow-up - Risk management of advanced therapy medicinal products [24]] 


\section{2.68 clinical hold}

delay of a proposed clinical trial or suspension of an ongoing clinical trial

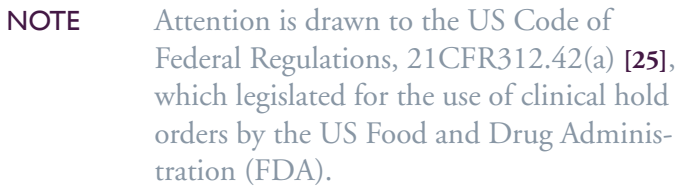

\subsection{9 clinical investigator}

medical researcher who is responsible for a clinical trial's protocol

NOTE See also chief investigator and principal investigator.

\subsection{0 clinical research organization (CRO)}

organization that assumes, as an independent contractor with the sponsor of a clinical trial, one or more of the obligations of the sponsor with respect to the clinical trial

NOTE I These obligations might include design of a protocol, selection or monitoring of investigations, evaluation of reports and preparation of materials to be submitted to a relevant authority.

NOTE 2 See also contract manufacturing organization (CMO) and contract research organization (contract RO).

\section{| 2.71 clinical translation}

process of taking a treatment from the laboratory to testing in volunteers 


\subsection{2 clinical trial}

investigation in human subjects intended to discover or verify the safety and efficacy of a therapy

NOTE Legal definitions applicable in the EU and USA are given in Table A.1.

2.73 clone

genetically identical copy of a cell or organism

I 2.74 cloning

isolation and production of a genetically identical copy of a cell or organism

NOTE I This can be conducted via somatic cell nuclear transfer.

NOTE 2 This is to be distinguished from molecular or gene cloning, which refers to the identification and copying of a specific gene sequence rather than a whole cell or organism.

\section{2.75 clonogenic cell}

single cell able to proliferate into a colony of genetically identical cells

\subsection{6 closed system}

system in which a medicinal product is not exposed to the immediate room environment during manufacture

[derived from the European Commission's Eudralex: The Rules Governing Medicinal Products in the European Union, Volume 4, draft Annex 2 [26]] 


\section{2.77 colony forming unit (CFU)}

macroscopic colony formed after the introduction of one or more microorganisms to microbiological growth media

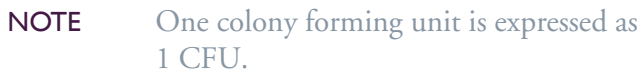

[US Food And Drug Administration's Guidance for Industry - Sterile Drug Products Produced by Aseptic Processing Current Good Manufacturing Practice [27]]

2.78 combination cell therapy

combination product containing a cell therapy product

NOTE See also combination product and combined advanced therapy medicinal product (combined ATMP).

\subsection{9 combination product}

product that is a combination of a medicinal product and/or biological medicinal product and/or medical device

NOTE See also combination cell therapy and combined advanced therapy medicinal product (combined ATMP). 


\section{2.80 combined advanced therapy medicinal product (combined ATMP)}

product that incorporates one or more medical devices or one or more active implantable medical devices and either its cellular or tissue part contains viable cells or tissues, or its cellular or tissue part containing non-viable cells or tissues is liable to act upon the human body with action that can be considered as primary to that of the devices referred to

NOTE See also advanced therapy medicinal product (ATMP), combination cell therapy and combination product.

[European Regulation No. 1394/2007 [5]]

\subsection{1 comparability}

exercise to evaluate the impact of changes to a manufacturing process on the validity of quality, non-clinical and/or clinical data relating to a cell therapy product or its components

NOTE The components of a cell therapy product include, for example, cellular populations and cell banks.

\subsection{2 comparable}

conclusion that a medicinal product has highly similar quality attributes before and after manufacturing process changes and that no adverse impact on the safety or efficacy, including immunogenicity, of the product occurred

NOTE This conclusion can be based on an analysis

of quality attributes. In some cases, non-

clinical or clinical data might contribute to the conclusion.

[derived from ICH Harmonised Tripartite Guideline O_5E [28]] 


\subsection{3 comparative genomic hybridization (CGH)}

method for the analysis of copy number changes in the chromosomal DNA content of a cell or tissue

\subsection{4 competent authority}

person or organization that has the legally delegated or invested authority, capacity, or power to perform a designated function

NOTE This will sometimes be referred to as a national competent authority (NCA), since authorities in different countries have different responsibilities.

\subsection{5 conditioning}

$<$ patient care $>$ medical procedure used to prepare a patient for the application of a medicinal product NOTE Examples include therapeutic immunosuppression, destruction of the patient's bone marrow, use of hormones for stimulation or inhibition of certain physiological functions.

[European Medicines Agency's Guideline on safety and efficacy follow-up - Risk management of advanced therapy medicinal products [24]]

\subsection{6 confounding factor}

variable that has the potential to interfere with the interpretation of data resulting from a scientific study, technical study or clinical trial 


\subsection{7 contained use}

operation in which genetically modified organisms are cultured, stored, used, transported, destroyed or disposed of and for which physical, chemical and/ or biological barriers are used to limit their contact with the general population and the environment

[derived from European Directive 90/219/EEC (and amendments) [29]]

\subsection{8 contamination}

undesired introduction of impurities of a chemical or microbiological nature, or of foreign matter, into or onto a raw material, intermediate or active substance during production, sampling, packaging or repackaging, storage or transport

[derived from the European Commission's Eudralex: The Rules Governing Medicinal Products in the European Union, Volume 4, Part II [9]]

\subsection{9 contaminant}

impurity of a chemical or microbiological nature, or foreign matter, unintentionally introduced into or onto a raw material, intermediate or active substance during production, sampling, packaging or repackaging, storage or transport

[derived fromthe European Commission's Eudralex: The Rules Governing Medicinal Products in the European Union, Volume 4, Part II [9]]

\subsection{0 continued process verification}

assurance that during routine production a process remains in a state of control

[US Food And Drug Administration's Guidance for IndustryProcess Validation: General Principles and Practices [30]] 


\section{2.91 continuous cell line}

cell line that appears to have the capacity for indefinite cell division

NOTE See also finite cell line.

- 2.92 contract manufacturing organization (CMO)

organization performing some aspect of manufacturing on behalf of another party

NOTE See also clinical research organization (CRO) and contract research organization (contract RO).

I 2.93 contract research organization (contract RO)

organization that assumes, as an independent contractor with the sponsor of any type of research, one or more of the obligations of the sponsor

NOTE I These obligations might include design of a protocol, selection or monitoring of investigations, evaluation of reports and preparation of materials to be submitted to a relevant authority.

NOTE 2 See also contract manufacturing organization (CMO) and clinical research organization (CRO).

\subsection{4 control}

benchmark against which experimental observations are evaluated 


\subsection{5 controlled trial}

comparative clinical trial involving a control

\subsection{6 cord blood}

blood isolated from an umbilical cord at birth

I 2.97 cord blood stem cell

stem cell isolated from cord blood

- 2.98 cord blood transplantation

transfusion of cord blood

2.99 cosmesis

preservation, restoration or bestowing of bodily beauty

[Dorland's Medical Dictionary [31]]

\section{2.100 cost benefit analysis}

form of economic evaluation which attempts to value the consequences of a therapy in monetary terms in order to ascertain whether the beneficial consequences of the programme justify the costs

[derived from Methods for the Economic Evaluation of Health Care Programmes [32]]

\subsection{1 cross-contamination}

unintended presence of a cell or a material with another cell or material

NOTE This can occur during a cell manufacturing process as a result of the inadvertent switching or mixing of cell cultures.

[derived from ASTM F2312-11] 


\section{I.102 cryopreservation}

maintenance of the viability of cells, tissues and organs by the process of cryoprotection, cooling and storing at very low temperatures

NOTE See also vitrification.

\subsection{3 cryoprotectant}

agent used to protect cells, tissues and organs from damage that can occur during cooling and storing at very low temperatures

NOTE I An example of damage is intracellular ice crystal formation.

NOTE 2 See also cryoprotection.

\subsection{4 cryoprotection}

protection of cells, tissues and organs from damage that can occur during cooling and storing at very low temperatures

NOTE See also cryoprotectant

\subsection{5 culture medium}

nutrient supply used to support the growth and expansion of cells or to maintain tissue or organ cultures

\section{2.106 cytokine}

intercellular signalling biomolecule 


\subsection{7 cytoplasmic hybrid embryos (cybrid)}

admixed embryo created by replacing the nucleus of an animal egg or a cell derived from an animal embryo with a human cell or the nucleus of a human cell

[derived from the Human Fertilisation and Embryology Authority's report on hybrids and chimeras [14]]

\subsection{8 de-differentiation} regression of a cell to a less specialized phenotype

\subsection{9 differentiation}

development into a more specialized cell phenotype

\subsection{0 defined medium}

culture medium in which all components are known

\subsection{1 direct use}

donation and use of cells that does not involve storage in a cell bank

[derived from European Directive 2006/17/EC [33]]

\subsection{DNA profiling}

technique to identify an organism from its DNA NOTE Also known as DNA fingerprinting.

\subsection{DNA short tandem repeat profiling (DNA STR profiling)}

DNA profiling by recognizing short sequence elements present throughout a DNA molecule 


\section{2.114 donation}

process of providing human tissues or cells with informed consent

NOTE This does not include the donation of organs for transplantation as this is not part of regenerative medicine.

\subsection{5 donor}

source from which cells or tissues are derived for cell therapy and regenerative medicine

[derived from European Directive 2004/23/EC [2]]

\subsection{6 donor selection}

process of selecting donors against eligibility criteria

\subsection{7 dose}

prescribed quantity of a medicine or of a remedial agent

[Larousse Dictionary of Science and Technology [34]]

\subsection{8 dose finding study}

study in which different groups of patients are given different doses of a product to select the best doses for use in later, larger-scale trials

\subsection{9 double-blind trial}

randomized trial in which the clinician and patient are unaware of which arm of the trial the patient is on NOTE I See also single-blind trial.

NOTE 2 Contrasts with open-label trial. 


\section{2.120 downstream processing}

technologies involved in the recovery and purification of products

NOTE Contrast with upstream processing.

\subsection{1 efficacy follow-up}

systematic collection and collation of data that is designed in a way that enables learning about the efficacy or effectiveness of a medicinal product

NOTE It can include active surveillance, clinical trials, observational trials and passive surveillance.

[European Medicines Agency's Guideline on safety and efficacy follow-up - Risk management of advanced therapy medicinal products [24]]

\subsection{2 eligibility criteria}

predetermined criteria for establishing whether an individual may or may not be entitled to be chosen

NOTE Also known as inclusion and exclusion criteria.

\section{2.123 embryonic stem cell}

undifferentiated cell derived from a pre-blastocyst or blastocyst that is pluripotent

\section{2.124 embryonic stem cell line}

cell line consisting of embryonic stem cells 


\section{- 2.125 encapsulation}

procedure by which biological materials are enclosed within a microscopic or macroscopic semipermeable barrier

[derived from ASTM F2312-11]

\section{2.126 endpoint}

overall outcome that a protocol is designed to evaluate

\section{2.127 engineered cells \&/or tissues}

cells or tissues that have been subjected to substantial manipulation, so that the biological characteristics, physiological functions or structural properties relevant for the intended regeneration, repair or replacement are achieved; and that are not intended to be used for the same essential function or functions in the recipient as in the donor

NOTE The manipulations listed in Annex I to European Regulation No. 1394/2007 [5], in particular, are not considered as substantial manipulations.

[European Regulation No. 1394/2007 [5]]

\section{I.128 engraftment}

process of integration of cellular material into a recipient 


\section{2.129 epigenetic}

heritable change in the heritable pattern of gene expression that is mediated by mechanisms other than alterations in the primary nucleotide sequence of a gene

NOTE For example, DNA methylation or histone modifications.

[derived from Epigenetic mechanisms of gene regulation [35]]

\section{2.130 ethics committee}

independent body consisting of healthcare professionals and non-medical members, whose responsibility it is to protect the rights, safety and well-being of human subjects involved in a study

NOTE I Legal definitions applicable in the EU and USA are given in Table A.1.

NOTE 2 A hierarchy of ethical committees exists. The committees are known as the local research ethics committee (LREC), the multi-centre research ethics committee (MREC) and the central office for research ethics committee (COREC).

\subsection{1 ex vivo}

outside the living body

\subsection{2 excipient}

ingredient added intentionally to an active substance, which does not have pharmacological properties in the quantity used

[derived from ICH Harmonised Tripartite Guideline Q1A(R2) [36]] 


\section{2.133 extracellular matrix (ECM)}

non-cellular matrix surrounding cells

\subsection{4 extracorporeal}

situated or occurring outside the body

\subsection{5 false negative}

<statistics> erroneously recognized as bad or false NOTE Contrasts with false positive.

\section{2.136 false positive}

$<$ statistics > erroneously recognized as good or true NOTE Can be due to a failure in an alerting system or due to an error made in a statistical decision process.

\subsection{7 feeder cell}

cell used in co-culture to sustain the viability and desired characteristics of other cells

\subsection{8 fetal stem cell}

multipotent stem cell originating from a fetus that has the potential to differentiate into or generate a limited range of specialized cell types

\subsection{9 finite cell line}

cell line that can be maintained for a limited number of population doublings before it becomes senescent and ultimately loses the ability to divide NOTE See also continuous cell line. 


\subsection{0 flow cytometry}

technique that measures and analyses light scatter and fluorescence from single cells as they flow in a fluid stream through a laser beam

NOTE This can be used to determine the phenotype of single cells.

\subsection{1 fluorescence activated cell sorting (FACS)}

sorting of a heterogeneous mixture of cells into two or more containers, one cell at a time, using the specific light scattering and fluorescent characteristics of each cell

NOTE See also magnetic-based cell sorting.

[derived from The Williams Dictionary of Biomaterials [17]]

\subsection{2 gene expression profile} (transcriptome)

spectrum of mRNA levels resulting from gene activity at a given time

\subsection{3 gene therapy}

deliberate manipulation of genetic material into cells for therapeutic purpose

NOTE See also gene therapy medicinal product. 


\section{2.144 gene therapy medicinal product}

biological medicinal product which contains an active substance which contains or consists of a recombinant nucleic acid used in or administered to human beings with a view to regulating, repairing, replacing, adding or deleting a genetic sequence; and whose therapeutic, prophylactic or diagnostic effect relates directly to the recombinant nucleic acid sequence it contains, or to the product of genetic expression of this sequence

NOTE I This does not include vaccines against infectious diseases.

NOTE 2 See also gene therapy.

[European Directive 2001/83/EC (and amendments) [1]]

\subsection{5 gene transfer}

process of transferring a gene into cells, involving an expression system contained in a delivery system known as a vector, which can be of viral as well as non-viral origin

NOTE After gene transfer, genetically modified cells are also termed transduced cells.

[European Commission's Eudralex: The Rules Governing Medicinal Products in the European Union, Volume 4, draft Annex 2 [26]]

\section{2.146 genetic locus}

specific location of a gene or DNA sequence on a chromosome 


\subsection{7 genetically modified organism (GMO)}

organism, with the exception of human beings, in which the genetic material has been altered in a way that does not occur naturally by mating and/ or natural recombination

[derived from European Directive No. 2001/18/EC (and amendments) [37]]

\subsection{8 genotype}

genetic constitution of an individual cell or organism

\section{2.149 Good Cell Culture Practice (GCCP)}

guidelines to define minimum standards in cell and tissue culture

NOTE Also known as current Good Cell Culture Practice (cGCCP).

\section{I.150 Good Clinical Practice (GCP)}

regulations, codes and guidelines covering the conduct of clinical trials

NOTE Also known as current Good Clinical Practice (cGCP).

\subsection{Good Laboratory Practice (GLP)}

regulations, codes and guidelines for laboratories conducting non-clinical studies

NOTE Also known as current Good Laboratory

Practice (cGLP). 


\section{2.152 Good Manufacturing Practice (GMP)}

regulations, codes and guidelines for the manufacture of cell therapy products, medicinal products, medical devices, diagnostic products, food products and active substances

NOTE Also known as current Good Manufacturing Practice (cGMP).

\section{2.153 Good Tissue Practice (GTP)}

regulations, codes and guidelines for the manufacture of cell therapy products

NOTE Also known as current Good Tissue Practice (cGTP).

\subsection{4 graft versus host disease (GVHD)}

aggressive immune response caused when T-cells derived from donor cells recognize the tissue of a recipient

NOTE This can occur following a stem cell or bone marrow transplantation.

\subsection{5 growth factor}

naturally occurring protein capable of stimulating cellular proliferation and/or differentiation

\subsection{6 haemocytometer}

glass slide with a chamber for counting cells in a given volume

\subsection{7 haematopoiesis}

formation of blood lineages from haematopoietic stem cells 


\subsection{8 haematopoietic stem cell (HSC)}

stem cell that gives rise to all red and white blood cells and platelets

[derived from the Stem Cell Information Glossary [20]]

\subsection{Hayflick limit}

number of divisions a cell can undergo before it stops dividing further

\subsection{0 heterologous use}

different use

\section{I.161 heterotopic}

different anatomical location

\section{I.162 histocompatibility}

measure of the extent to which implanted cells are immunologically matched to the recipient

\section{I.163 histology}

microscopic study of the form and structure of tissues

I 2.164 homologous use

same essential function

\section{2.165 homotopic}

same anatomical location

NOTE Also known as orthotopic. 


\section{2.166 human chimera embryo}

admixed embryo created by inserting animal cells into a human embryo

[derived from the Human Fertilisation and Embryology

Authority's report on hybrids and chimeras [14]]

I 2.167 human leucocyte-associated antigen (HLA)

highly polymorphic molecule required for antigen presentation encoded within the human major histocompatibility complex

NOTE See also tissue typing.

\subsection{8 immobilization}

entrapment of materials within, or bound to, a matrix

[derived from ASTM F2312-11]

\subsection{9 immortal}

capacity of cells to proliferate indefinitely

\subsection{0 immunocytochemistry}

method that uses antibodies to identify, locate and visualize specific molecules in or on the surface of cells

\subsection{1 immunogenicity}

extent to which an administered substance provokes an immune response in the recipient 


\subsection{2 immunohistochemistry}

method that uses antibodies to identify, locate and visualize specific molecules or cell types in tissue sections

\subsection{3 immunological rejection}

failure of a recipient's body to accept a transplanted tissue or organ as the result of immunological incompatibility

\section{2.174 immunomodulation}

therapeutic strategy aimed at altering the normal course of an immune response, either enhancing it for the purpose of vaccination or suppressing its effects if deleterious

NOTE This is often used in the case of allograft rejection and autoimmunity.

\subsection{5 immunotherapy}

planned intervention in the normal course of a potentially detrimental immune response, intended to solicit an outcome of benefit to an individual

\subsection{6 impurity}

component present in a substance that is not the desired substance

\subsection{7 in vitro}

within an artificial environment

\subsection{8 in vivo}

within the living body 


\subsection{9 in-process control}

checks performed during processing in order to monitor and if necessary adjust the process to ensure that the product conforms to its specification

NOTE I Environmental conditions and equipment can, for example, be monitored as part of in-process control.

NOTE 2 One element of in-process control is process analytical technology (PAT).

\section{- 2.180 induced pluripotent stem cell (iPS cell)}

human embryonic stem cell-like cell that is produced by reprogramming a cell to a state of pluripotency

\subsection{1 informed consent}

voluntary decision to take part in a clinical trial or donate cells or tissues, after being duly informed of the nature, significance, implications and risks associated with the clinical trial or donation, by any person capable of giving consent or, where the person is not capable of giving consent, by his or her legal representative

NOTE I Legal definitions applicable in the EU and USA for clinical trials are given in Table A.1.

NOTE 2 The annex to European Directive 2004/23/

EC [2] specifies the information that must be provided to a donor, their relatives or any person granting authorization on behalf of a donor.

NOTE 3 In the UK, detailed advice on when and how consent should be sought, and what information should be given is provided in the Human Tissue Authority Code of practice 1 [38]. 


\subsection{2 inner cell mass (ICM)}

cluster of cells inside a blastocyst

NOTE These cells are used to generate embryonic stem cells.

[derived from the Stem Cell Information Glossary [20]]

\subsection{3 intermediate}

material produced during steps in the processing of an active substance that undergoes further molecular change or purification before it becomes an active substance

NOTE Intermediates may or may not be isolated.

[derived from the European Commission's Eudralex: The Rules Governing Medicinal Products in the European Union,

Volume 4, Part II [9]]

\subsection{4 investigational medicinal product (IMP)}

pharmaceutical form of an active substance or placebo being tested or used as a reference in a clinical trial

NOTE I This includes products already with a marketing authorization but used or assembled (formulated or packaged) in a way different from the authorized form, or when used for an unauthorized indication, or when used to gain further information about the authorized form.

NOTE 2 Also known in the USA as investigational new drug (IND).

[derived from European Directive 2001/20/EC [39]] 


\section{2.185 karyotyping}

assessment of the complete set of all chromosomes of a cell that can identify chromosomal abnormalities

\section{2.186 magnetic-based cell sorting}

sorting of a heterogeneous mixture of cells via mixing with magnetic beads coated with antibodies against specific cell surface antigens, followed by separation and selection using a column placed in a magnetic field

NOTE See also fluorescence activated cell sorting (FACS).

\subsection{7 major histocompatibility complex (MHC)}

genetic locus encompassing a family of highly polymorphic genes encoding proteins that regulate immune responses

NOTE The human leucocyte-associated antigen (HLA) is encoded within the human MHC.

\section{2.188 manufacture}

any or all of the steps in the recovery, screening, testing, processing, storage, labelling or packaging of any cell therapy product

[derived from ASTM F2312-11] 


\section{2.189 marketing authorization}

authorization by a relevant authority for a medicinal product to be placed on the market

NOTE I A new drug application (NDA) is the vehicle by which drug sponsors formally propose that the US Food and Drug Administration approve a new pharmaceutical for sale and marketing in the USA.

NOTE 2 A biologics licence application (BLA) is a request for permission to introduce, or deliver for introduction, a biologic product into interstate commerce in the USA.

\section{2.190 marrow stromal cell}

differentiated progeny from mesenchymal stem cells

NOTE Typically a heterogeneous population including a range of stromal cells at different stages of differentiation and of different composition or nature including osteoblasts (bone), chondrocytes (cartilage) and adipocytes (fat).

\section{2.191 master cell bank (MCB)}

cell bank prepared from an aliquot of a single pool of cells

NOTE I Generally the pool of cells is prepared from a clone under defined conditions.

NOTE 2 In a two-tiered cell banking system, the $\mathrm{MCB}$ is used to derive the working cell bank (WCB).

[derived from ICH Harmonised Tripartite Guideline O_5D [21]] 


\section{2.192 medical device}

instrument, apparatus, appliance, software, material or other article, whether used alone or in combination, including the software intended by its manufacturer to be used specifically for diagnostic and/ or therapeutic purposes and necessary for its proper application, intended by the manufacturer to be used for human beings for the purpose of: diagnosis, prevention, monitoring, treatment or alleviation of disease; diagnosis, monitoring, treatment, alleviation of or compensation for an injury or handicap; investigation, replacement or modification of the anatomy or of a physiological process; control of conception, and which does not achieve its principal intended action in or on the human body by pharmacological, immunological or metabolic means, but which may be assisted in its function by such means

[European Directive 93/42/EEC (and amendments) [40]]

\subsection{3 medicinal product}

substance or combination of substances presented as having properties for treating or preventing disease in human beings; or any substance or combination of substances which may be used in or administered to human beings either with a view to restoring, correcting or modifying physiological functions by exerting a pharmacological, immunological or metabolic action, or to making a medical diagnosis

[European Directive 2001/83/EC (and amendments) [1] 


\section{2.194 mesenchymal stem cell}

multipotent bone marrow-derived non-haematopoietic stem cell with the capacity to generate cells of the stromal lineage

NOTE I Examples of cell types that can be derived from mesenchymal stem cells include osteoblasts, chondrocytes and adipocytes.

NOTE 2 These cells are also referred to as mesenchymal stromal stem cells.

\subsection{5 microarray}

set of DNA or protein molecules spotted onto a solid matrix for use in multiplex probing of a biological sample to determine gene or protein expression, marker pattern or the nucleotide sequence of DNA/ RNA

\subsection{6 minimal manipulation}

processing that does not alter the relevant biological characteristics of cells or tissue

NOTE Contrasts with substantial manipulation.

[derived from the US Code of Federal Regulations, 21CFR1271.3(f)(2) [41]]

\section{2.197 minor histocompatibility antigen ( $\mathrm{mH}$ antigen)}

naturally polymorphic protein that is recognized as foreign by the immune system of the recipient, potentially contributing to the rejection of a tissue 


\section{I.198 morula}

pre-implantation embryo of about 30 cells produced after cleavage of the zygote around 96 hours following fertilization

NOTE I The morula is a sphere of blastomeres contained within a glycoprotein membrane (zona pellucida).

NOTE 2 See also blastocyst.

\subsection{9 multipotent}

having the ability to develop into a limited number of cell types

\subsection{0 mycoplasma}

parasitic bacterium without a cell wall, which belongs to the phylum Mollicutes

NOTE Mycoplasma is a common contaminant in cell culture and can cause serious deleterious effects on cells. It is resistant to many antibiotics and as such is hard to remove entirely from a cell culture.

\subsection{1 necrosis}

non-programmed cell death

NOTE See also apoptosis.

\subsection{2 non-clinical study}

study performed in vitro and/or in vivo (in animals) to provide data on an investigational medicinal product

NOTE See also preclinical study. 


\subsection{3 non-interventional trial}

trial where a medicinal product is prescribed in the usual manner in accordance with the terms of the marketing authorization

NOTE The assignment of the patient to a particular therapeutic strategy is not decided in advance by a trial protocol but falls within current practice and the prescription of the medicine is clearly separated from the decision to include the patient in the trial. No additional diagnostic or monitoring procedures are applied to the patients and epidemiological methods are used for the analysis of collected data.

[derived from European Directive 2001/20/EC [39]]

\section{2.204 observational trial}

trial to assess biomedical health outcomes in predetermined groups of individuals where the investigator does not assign specific interventions to the individuals

\subsection{5 off-label use}

use of a medicinal product to treat a separate medical condition to that which it has been approved for

\subsection{6 open-label trial}

randomized trial in which both the clinician and patient are aware of which arm of the trial the patient is on

NOTE Contrasts with single-blind trial and double-blind trial. 


\subsection{7 organ}

differentiated part of the human body, formed by different tissues, that maintains its structure, vascularization and capacity to develop physiological functions with a significant level of autonomy

NOTE A part of an organ is also considered to be an organ if its function is to be used for the same purpose as the entire organ in the human body, maintaining the requirements of structure and vascularization.

[derived from European Directive 2010/45 [4]]

\section{2.208 orphan drug}

medicinal product designed to treat a rare disease

\subsection{9 parallel group}

treatment and control are allocated to different individuals

\subsection{0 parthenogenesis}

development of a female embryo without fertilization from the male

\section{2.211 parthenogenetic stem cell line}

stem cell line derived from a one-pronuclear oocyte formed following parthenogenesis

NOTE Derivation of such a line avoids ethical issues associated with the derivation of human embryonic stem cells and also enables the development of homologous cell lines suitable for transplantation. 


\subsection{2 passage}

transfer of cells from one cell culture environment to another

\subsection{3 passage number}

number of times cells have been transferred from one cell culture environment to another

\section{2.214 passive surveillance}

surveillance conducted by a method that relies on the collection of unsolicited initial patient safety information

NOTE I Examples include spontaneous reporting schemes, literature monitoring and Internet searches.

NOTE 2 Contrasts with active surveillance.

[derived from the European Commission's Eudralex: The Rules Governing Medicinal Products in the European Union, Volume 9A [12]]

\section{- 2.215 pathogen}

disease-producing agent or microorganism

[Dorland's Pocket Medical Dictionary [31]]

\section{2.216 performance indicator}

measurable value used to quantify quality objectives to reflect the performance of an organization, process or system

NOTE Also known as performance metrics.

[derived from ICH Harmonised Tripartite Guideline Q10 [42]] 


\section{2.217 permitted embryo}

embryo licensed for use in vitro fertilization treatment

NOTE I The licensing of permitted embryos is covered by the Human Fertilisation and Embryology Act 1990 (and amendments) [6].

NOTE 2 See also admixed embryo.

\subsection{8 pharmacodynamics}

study of the biochemical and physiological effects of medicinal products and the mechanisms of their actions

[Dorland's Pocket Medical Dictionary [31]]

\subsection{9 pharmacokinetics}

study of the fate of drugs in a body

NOTE This includes a mathematical account of their absorption, distribution, metabolism and excretion.

[derived from the Committees on Toxicity, Mutagenicity, Carcinogenicity of Chemicals in Food, Consumer Products and the Environment's Annual Report 2006 [43]]

\section{2.220 pharmacology}

study of the uses, effects and actions of medicinal products on living systems 


\section{2.221 pharmacovigilance}

science relating to the detection, assessment, understanding and prevention of adverse effects from medicines

[derived from the World Health Organization's The Importance of Pharmacovigilance: Safety Monitoring of Medicinal Products [44]]

2.222 phase I trial

clinical trial performed in patients to determine safety data

NOTE Preliminary efficacy data can also be obtained from a phase I trial.

\section{2.223 phase II trial}

clinical trial performed in patients to ascertain safety and efficacy

NOTE This can be further separated into a phase IIa trial and phase IIb, which determine dosing requirements and efficacy respectively.

\section{2.224 phase III trial}

clinical trial that involves a large number of patients in different clinical settings to determine safety and efficacy

\section{2.225 phase IV trial}

post-authorization clinical trial using pharmacovigilance to determine the long-term side effects of medicinal products 


\subsection{6 phenotype}

physical and biological characteristics of a cell or organism as determined by both genetic make-up and environmental influences

\subsection{7 placebo}

product or treatment that mimics a medicinal product but contains no active substance

\subsection{8 placebo controlled trial}

controlled trial in which the control is a placebo

\section{2.229 placing on the market}

first making available in return for payment or free of charge a medicinal product with a view to distribution and/or use on the market

[derived from European Directive 90/385/EEC (and amendments) [10]]

\subsection{0 plasmid}

piece of DNA usually present in a bacterial cell as a circular entity separated from the cell chromosome NOTE It can be modified by molecular biology techniques, purified out of the bacterial cell and used to transfer its DNA to another cell.

[European Commission's Eudralex: The Rules Governing Medicinal Products in the European Union, Volume 4, draft Annex 2 [26]]

\section{- 2.231 plating efficiency}

measure of the number of colonies originating from single cells 


\section{| 2.232 pluripotent}

having the ability to develop into all cell lineages, except those related to extraembryonic tissues

NOTE I In humans there are three cell lineages from which all cell types, except extraembryonic tissues (e.g. placenta), are developed. These are the endoderm, mesoderm and ectoderm.

NOTE 2 Contrasts with unipotent.

\section{2.233 polymerase chain reaction (PCR)}

technique for the in vitro amplification of a specific target DNA sequence from a background of non-target DNA

\section{2.234 population doubling}

measured doubling of cell numbers

\subsection{5 porosity}

property of a solid which contains an inherent or induced network of channels and open spaces

NOTE This can be measured by the ratio of

the pore (void) volume to the apparent

(total) volume of a porous material and is

commonly expressed as a percentage.

[ASTM F2312-11] 


\subsection{6 post-authorization safety study}

study relating to an authorized medicinal product conducted with the aim of identifying, characterizing or quantifying a safety hazard, confirming the safety profile of the medicinal product, or of measuring the effectiveness of risk management measures

NOTE This can be one element in a phase IV trial.

[Directive 2001/83/EC (and amendments) [1]]

\subsection{7 post-market surveillance}

practice of monitoring the safety or efficacy of a medicinal product or medical device after it has been released onto the market

NOTE 2 See also clinical follow-up.

\subsection{8 potency}

$<$ medicinal product $>$ quantitative measure of biological activity based on those attributes of a product that are linked to relevant biological properties

[derived from ICH Harmonised Tripartite Guideline OQ6B [45]]

$<$ stem cell > extent to which a stem cell can differentiate along distinct cell lineage pathways

NOTE For example, whether a stem cell is multipotent or pluripotent.

\subsection{9 power of study}

$<$ statistics $>$ number or percentage that indicates the probability a study will obtain a statistically significant effect 


\section{2.240 preclinical study}

study performed in vitro and/or in vivo (in animals) to provide data to support initiation of clinical trial phases and/or support marketing authorization NOTE See also non-clinical study.

\section{I.241 precursor cell}

cell at a stage of development immediately prior to terminal differentiation

NOTE See also progenitor cell and somatic cell.

\section{I.242 preservation}

prevention or retardation of the biological or physical deterioration of cells or tissues

NOTE I This can be achieved during cell or tissue processing, for example, through the use of chemical agents or alterations in environmental conditions.

NOTE 2 See cryopreservation.

[derived from European Directive 2004/23/EC [2]]

\section{2.243 primary cell culture}

culture of cells isolated directly from tissue

\subsection{4 principal investigator}

investigator who takes overall charge at a clinical trial centre

NOTE See chief investigator and clinical investigator. 


\section{2.245 process analytical technology (PAT)}

system for designing, analysing and controlling manufacturing through timely measurements, during processing, of critical quality and performance attributes of raw and in-process materials and processes with the goal of ensuring final product quality

[ICH Harmonised Tripartite Guideline O8(R2) [46]]

\subsection{6 progenitor cell}

cell which is at a more advanced stage of differentiation than a stem cell but is not yet fully differentiated

NOTE See also precursor cell and somatic cell.

\section{2.247 proliferation}

growth of a cell population by cell division

\subsection{8 prospective trial}

clinical trial that observes outcomes during a trial and relates these to influencing factors

NOTE I Influencing factors include suspected risk or protection factors.

NOTE 2 Contrast with retrospective trial

[derived from The Oxford Dictionary of Statistical Terms [47]]

\subsection{9 protein expression}

translational and post-translational processing of proteins 


\subsection{0 protocol}

$<$ clinical trial > document that describes the objectives, design, methodology, statistical considerations and organization of a clinical trial

NOTE The term protocol refers to the protocol, successive versions of the protocol and protocol amendments.

[derived from European Directive 2001/20/EC [39]]

\subsection{1 provenance}

adequate knowledge of the source of a material, cells or reagents used in the derivation of cells in order for a risk assessment of contamination or infection to be made

NOTE I Provenance is essential when a material, cells or reagents are intended for clinical use.

NOTE 2 Provenance can include knowledge of the medical histories of donors of gametes used to derive embryos.

\section{2.252 purity}

level of freedom from impurities

\section{2.253 qualification}

<manufacturing $>$ confirmation by examination and provision of objective evidence that equipment functions in the manner intended by the manufacturer

NOTE I This includes examination of the installation, operation and performance of equipment.

NOTE 2 See also validation. 


\section{2.254 qualified person (QP)}

person responsible for certifying that a batch of medicinal product conforms to requirements prior to release

NOTE European Directive 2001/83/EC [1] specifies requirements for a $\mathrm{QP}$.

\subsection{5 qualified person responsible for pharmacovigilance (QPPV)}

person responsible for pharmacovigilance for licensed medicinal products

NOTE European Directive 2001/83/EC [1] specifies requirements for a QPPV.

\subsection{6 quality}

degree to which a set of inherent properties of a product, system or process fulfils requirements

[ICH Harmonised Tripartite Guideline Q9 [48]]

\section{ـ 2.257 quality assurance (OA)}

total sum of organized arrangements made with the object of ensuring that medicinal products are of the quality required for their intended use

[derived from the European Commission's Eudralex: The Rules Governing Medicinal Products in the European Union, Volume 4, Part I, Chapter 1 [49]]

\subsection{8 quality by design (QDbD)}

systematic approach to development that begins with predefined objectives and emphasizes product and process understanding and process control, based on sound science and quality risk management

[ICH Harmonised Tripartite Guideline Q8(R2) [46]] 


\section{2.259 quality control (OC)}

process or set of processes or measures used to maintain predefined standards to assure the quality of a product

\subsection{0 quality system}

documented organizational structure, defined responsibilities, procedures, processes and resources for implementing quality management including all activities which contribute to quality, directly or indirectly

[derived from European Directive 2006/17/EC [33]]

\subsection{1 quiescence}

stage in a cell cycle when the cell stops dividing

\subsection{2 randomized trial}

trial in which participants are randomly (i.e. by chance) assigned to one of two or more treatment arms of a clinical trial

NOTE Examples include double-blind trial open-label trial and single-blind trial.

\section{2.263 raw material}

starting materials, reagents and solvents intended for use in the production of intermediates or an active substance

[derived from the European Commission's Eudralex: The Rules Governing Medicinal Products in the European Union, Volume 4, Part II [9]] 


\section{- 2.264 real time release testing (RTR testing)}

evaluation and ensurance of the quality of an in-process product and/or final product based on process data

NOTE Process data typically include a combination of measured material attributes and process controls.

[derived from ICH Harmonised Tripartite Guideline Q8(R2) [46]]

\subsection{5 recall}

removal or correction of a marketed product that a relevant authority considers to be in violation of their laws

\section{2.266 regenerative medicine}

process of replacing or regenerating human cells, tissues or organs to restore or establish normal function

[derived from Regenerative Medicine, 2008, 3(1), 1-5 [50]]

\section{2.267 release criteria}

predetermined criteria against which a product is assessed to determine its suitability for release

NOTE These measurements can include identity, purity, impurities, sterility, potency, cell viability and total cell number.

[derived from the European Medicines Agency's Guideline on Human Cell-Based Medicinal Products [22]]

\subsection{8 reproductive cloning}

production of identical animals via cloning 


\subsection{9 reprogramming}

$<$ genetics $>$ facilitating the uptake of genes by a cell

NOTE This is a method frequently used to derive induced pluripotent stem cells (iPS cells).

\subsection{0 retrospective trial}

clinical trial that identifies outcomes from data that has previously been collected and relates these to influencing factors

NOTE I Influencing factors include suspected risk or protection factors.

NOTE 2 Contrast with prospective trial.

[derived from The Oxford Dictionary of Statistical Terms [47]]

\section{2.271 risk}

combination of the probability of occurrence of harm and the severity of that harm

[ISO/IEC Guide 51:1999]

NOTE See also risk analysis and risk management.

\section{. 2.272 risk analysis}

systematic use of available information to identify hazards and to estimate the risks

NOTE Risk analysis includes examination of different sequences of events that can produce hazardous situations and harm.

[ISO/IEC Guide 51:1999] 


\section{2.273 risk management}

systematic application of management policies, procedures and practices to the tasks of analysing, evaluating and controlling risk

[BS EN ISO 14971:2009, 2.22]

NOTE Attention is drawn to the European Commission's Eudralex: The Rules Governing Medicinal Products in the European Union, Volume 9A [12], which in the context of pharmacovigalance, specifically defines:

a risk management system as a set of pharmacovigilance activities and interventions designed to identify, characterize, prevent or minimize risks relating to medicinal products, and the assessment of the effectiveness of those interventions;

EU risk management plan (EU-RMP) as a document that describes a risk management system, which is specific to a particular product; and

risk minimization as activities used to reduce the probability of an adverse reaction occurring or its severity should it occur.

\subsection{4 safety}

freedom from unacceptable risk

[ISO/IEC Guide 51:1999] 


\subsection{5 safety follow-up}

systematic collection and collation of data that is designed in a way that enables learning about the safety of a medicinal product

NOTE It can include active surveillance, clinical trials, observational trials and passive surveillance.

[European Medicines Agency's Guideline on safety and efficacy follow-up - Risk management of advanced therapy medicinal products [24]]

\subsection{6 same surgical procedure}

surgical intervention, or series of interventions, related to the same therapeutic goal on an individual under the continuous care of a medical doctor or team of medical doctors for the purpose of obtaining a specific therapeutic effect

\section{| 2.277 scaffold}

support, delivery vehicle or matrix for facilitating the migration, binding or transport of cells or bioactive agents

[derived from ASTM F2312-11]

\subsection{8 scale out (or scale horizontally)}

increasing production by an increase in the number of units rather than increasing the size of the process

\section{2.279 scale up (or scale vertically)}

increasing the size of the process rather than increasing production by an increase in the number of units 


\section{2.280 seeding density}

number of cells used to initiate or progress a cell culture

NOTE Usually expressed as total number of cells per unit area or volume.

\subsection{1 self-renewal}

ability to continuously undergo cell division where each daughter cell is identical

\subsection{2 senescence}

decline or degeneration related to cellular ageing

\subsection{3 sensitivity}

$<$ statistics > degree of response to a change in input/ components of the test

\section{2.284 serious adverse event (SAE)}

untoward occurrence associated with the procurement, testing, processing, storage and distribution of tissues and cells that might lead to the transmission of a communicable disease, to death or lifethreatening, disabling or incapacitating conditions for patients or that might result in, or prolong, hospitalization or morbidity

NOTE I A legal definition applicable in the EU for clinical trials is given in Table A.1.

NOTE 2 See also adverse event.

[European Directive 2004/23/EC [2]] 


\subsection{5 serious adverse reaction (SAR)}

unintended response, including a communicable disease, in the donor or in the recipient associated with the procurement or human application of tissues and cells that is fatal, life-threatening, disabling, incapacitating or which results in, or prolongs, hospitalization or morbidity

NOTE I A legal definition of SAR applicable in the EU for clinical trials is given in Table A.1.

NOTE 2 See also adverse reaction and unexpected adverse reaction (UAR).

[European Directive 2004/23/EC [2]]

\subsection{6 sham procedure}

procedure that is performed as a control and that is similar to but omits a key therapeutic element of the treatment or procedure under investigation

\subsection{7 side effect}

undesired action or effect resulting from therapeutic treatment

\subsection{8 significance}

$<$ statistics $>$ fixed probability of wrongly rejecting the null hypothesis

\subsection{9 single-blind trial}

randomized trial in which either the clinician or patient are unaware of which arm of the trial the patient is on

NOTE I See also double-blind trial.

NOTE 2 Contrasts with open-label trial. 


\section{2.290 somatic cell}

fully differentiated cell from an adult body or fetus

NOTE I These cells can be autologous, allogeneic or xenogeneic somatic cells that have been manipulated or altered ex vivo to be administered in humans to obtain a therapeutic, diagnostic or preventive effects.

NOTE 2 See also progenitor cell and precursor cell.

[derived from the UK Stem Cell Bank's Code of Practice for the Use of Human Stem Cell Lines [13]]

\subsection{1 somatic cell nuclear transfer (SCNT)}

technique that combines an enucleated egg (nucleus removed) and the nucleus of a somatic cell to make an embryo

\subsection{2 somatic cell therapy medicinal product}

biological medicinal product which contains or consists of cells or tissues that have been subject to substantial manipulation so that biological characteristics, physiological functions or structural properties relevant for the intended clinical use have been altered, or of cells or tissues that are not intended to be used for the same essential functions in the recipient and the donor; and is presented as having properties for, or is used in or administered to human beings with a view to treating, preventing or diagnosing a disease through the pharmacological, immunological or metabolic action of its cells or tissues

NOTE The manipulations listed in Annex I to

European Regulation No. 1394/2007 [5], in particular, are not considered as substantial manipulations.

[Directive 2001/83/EC (and amendments) [1]] 


\subsection{3 specification}

predetermined set of criteria to which a medicinal product, active substance or intermediates thereof, should conform to be considered acceptable for its intended use

[derived from ICH Harmonised Tripartite Guideline O6B [45]]

\section{2.294 specificity}

$<$ statistics $>$ probability of a true negative being correctly identified

NOTE Contrasts with false negative.

\section{2.295 stability testing}

determination of the shelf life of a substance under anticipated storage and in use

NOTE I This includes, for example, assessment of the ability of cells to survive and maintain their potency.

NOTE 2 This applies to, for example, raw materials, starting materials, intermediates and final products.

[derived from the European Medicines Agency's Guideline on Human Cell-Based Medicinal Products [22]]

\section{2.296 standard operating procedure (SOP)}

detailed, written instructions to achieve uniformity of the performance of a specific function

[ICH Harmonised Tripartite Guideline E6(R1) [51]] 


\section{2.297 starting material}

raw material, intermediate or active substance that is used in the production of an active substance and that is incorporated as a fragment into the structure of the active substance

NOTE I Attention is drawn to European Directive 2001/83/EC (and amendments) [1], Annex 1, Part IV, which requires for somatic cell therapy medicinal products and tissue engineered products that additional substances (e.g. scaffolds, matrices, devices, biomaterials, biomolecules and/or other components) which are combined with manipulated cells of which they form an integral part shall be considered as starting materials, even if not of biological origin.

NOTE 2 See also cellular starting material.

[derived from ICH Harmonised Tripartite Guideline Q7 [11]]

\subsection{8 state of control}

condition in which a set of controls consistently provides assurance of continued process performance and product quality

[derived from ICH Harmonised Tripartite Guideline Q10 [42]]

\subsection{9 stem cell}

cell capable of both asymmetric cell division and self-renewal, and of providing cells capable of differentiation

\subsection{0 stem cell line}

cell line consisting of stem cells 


\section{2.301 sterile}

completely absent of any viable microorganisms

NOTE Sterility is determined through a validated process that demonstrates the absence of microorganisms at a specified statistical probability.

\subsection{2 stromal cells}

non-haematopoietic cells capable of supporting the growth of blood cells

NOTE Typically derived from bone marrow.

\subsection{3 subject}

individual who participates in a clinical trial as either a recipient of the investigational medicinal product or control

[derived from European Directive 2001/20/EC [39]]

\subsection{4 substantial manipulation}

manipulation of cells or tissue so that biological characteristics, physiological functions or structural properties relevant for the therapeutic application are achieved

NOTE I The following manipulations are not considered as substantial manipulations: cutting; grinding; shaping; centrifugation; soaking in antibiotic or antimicrobial solutions; sterilization; irradiation; cell separation, concentration or purification; filtering; lyophilization; freezing; cryopreservation: and vitrification.

NOTE 2 Contrasts with minimal manipulation

[derived from European Directive 2001/83/EC (and amendments) [1]] 


\section{2.305 syngeneic}

where donor and recipient are genetically identical individuals

NOTE For example, identical twins or animals of a single highly inbred strain.

\subsection{6 therapeutic cloning}

production of cells that exactly match the cells of a donor

\subsection{7 therapeutic immunosuppression}

suppression of the immune response in order to prevent the rejection of grafts or transplants or control autoimmune diseases

\section{2.308 therapy}

treatment intended to heal or relieve a disorder

\subsection{9 tissue}

aggregation of specialized cells united in the performance of a particular set of functions

[derived from ASTM F2312-11]

\section{2.310 tissue bank}

collection of tissues stored for research or clinical utility 


\subsection{1 tissue engineered product}

product that contains or consists of engineered cells and/or tissues, and is presented as having properties for, or is used in or administered to human beings with a view to, regenerating, repairing or replacing a human tissue

[European Regulation No. 1394/2007 [5]]

\subsection{2 tissue engineering}

use of a combination of cells, engineering, materials and methods to manufacture ex vivo living tissues and organs that can be implanted to improve or replace biological functions

NOTE Usually through the use of scaffolds for restoration or regeneration of tissues or organs.

\subsection{3 tissue establishment}

establishment where the activities of processing, preservation, storage or distribution of human tissue and cells are undertaken

NOTE I For example, a tissue bank or a unit of a hospital.

NOTE 2 It might also be responsible for procurement or testing of tissue and cells.

[derived from European Directive 2004/23/EC [2]]

\subsection{4 tissue typing}

process of determining the set of human leucocyteassociated antigens encoded within an individual's major histocompatibility complex

NOTE This is performed in order to determine the acceptance or rejection of a tissue graft prior to transplantation. 


\subsection{5 toxicology}

study of the potential of materials to harm health by virtue of their effect on biological systems

\subsection{6 totipotent}

having the ability to develop into all types of cell including extraembryonic tissues

NOTE An example of extraembryonic tissue is placenta.

\subsection{7 traceability}

ability to track tissues or cells by recording their status at all points from initial collection right through to either transplantation or disposal

NOTE Legal definitions applicable in the EU and USA are given in Table A.1.

\subsection{8 transgenic}

organism that contains a foreign gene in its normal genetic component

NOTE Such organisms might be produced in order to express biological pharmaceutical materials.

[derived from the European Commission's Eudralex: The Rules Governing Medicinal Products in the European Union, Volume 4, draft Annex 2 [26]]

\subsection{9 transgenic human embryo}

admixed embryo created by inserting animal genes into an early embryo

[derived from the Human Fertilisation and Embryology Authority's report on hybrids and chimeras [14]] 


\section{2.320 translation}

active turning of a basic science discovery into a safe and effective therapy deployed in routine clinical practice

\subsection{1 transplantation}

process of implanting cells, tissues or organs

[derived from ASTM F2312-11]

\subsection{2 transplantation tolerance}

state of induced immunological acceptance of a graft that would otherwise be rejected

\section{2.323 trophoblast}

outer cell layer of a blastocyst

NOTE It develops into extraembryonic tissue, such as placenta.

[derived from the Stem Cell Information Glossary [20]]

\subsection{4 tumour}

swelling of a part of the body caused by an abnormal growth of tissue whether benign or malignant

\section{2.325 tumour-associated antigen}

protein whose expression is predominantly restricted to a given type of tumour

NOTE This can serve as a target for a cancer vaccine.

\subsection{6 tumorigenicity}

tendency of cells to form a tumour 


\subsection{7 unexpected adverse reaction (UAR)}

adverse reaction, the nature, severity or outcome of which is not consistent with the summary of product characteristics

NOTE See also adverse reaction and serious adverse reaction (SAR).

[derived from European Directive 2001/83/EC (and amendments) [1]]

\subsection{8 unipotent}

having the ability to develop into only one cell type NOTE Contrasts with pluripotent.

\subsection{9 upstream processing}

technologies involved in the initial stages of product manufacture

NOTE I For example where cells are grown in a bioreactor.

NOTE 2 Contrasts with downstream processing.

\subsection{0 user requirement brief (URB)}

overarching, strategic document describing what outcomes an end user expects from a project as a whole

NOTE I It includes a description of the business, as well as the technical, need for a project.

NOTE 2 It is used, for example, for capital manufacturing projects licensed by a relevant competent authority, such as the Medicines and Healthcare products Regulatory Agency (MHRA).

NOTE 3 It is underpinned by user requirement specifications (URSs). 


\section{2.331 user requirement specification (URS)}

document describing what outcomes an end user expects from an individual component of a project

NOTE I Individual components of a project include individual products and systems.

NOTE 2 It is written in line with the requirements of a user requirement brief (URB) .

\section{2.332 validation}

means of establishing documented evidence that provides a high degree of assurance that a specific process, standard operating procedure, piece of equipment or environment will consistently produce a product meeting its predetermined specifications and quality attributes perform according to the intended specified outcomes

NOTE A process is validated to evaluate the performance of a system with regard to its effectiveness based on intended use.

[European Directive 2006/17/EC [33]]

\subsection{3 vector}

agent that can carry a DNA fragment into a host cell NOTE If it is used for reproducing the DNA fragment, it is named cloning vector. If it is used for expressing the fragment, it is named expression vector. 


\subsection{4 viral vector}

vector derived from a virus and modified by means of molecular biology techniques in a way as to retain some, but not all, the parental virus genes

NOTE If the genes responsible for virus replication capacity are deleted, the vector is made replication-incompetent.

[European Commission's Eudralex: The Rules Governing Medicinal Products in the European Union, Volume 4, draft Annex 2 [26]]

\subsection{5 vitrification}

form of cryopreservation whereby cells, tissues or organs are converted into a glass-like amorphous state prior to cooling to ultra-low temperatures

\subsection{6 whole bioprocessing}

$<$ allogeneic $>$ entire bioprocess from donor through to implantation of a cell therapy $<$ autologous $>$ entire bioprocess from patient biopsy through to implantation of a cell therapy

\subsection{7 working cell bank (WCB)}

cell bank prepared from aliquots of a homogeneous suspension of cells obtained from culturing cells from the master cell bank

[derived from ICH Harmonised Tripartite Guideline O5D [21]]

\subsection{8 xenogeneic}

where the donor and recipient belong to different species

[derived from ASTM F2312-11] 


\subsection{9 xenograft}

xenogeneic graft

\subsection{0 xenotransplantation}

procedure that involves the transplantation or infusion into a human recipient of either cells, tissues or organs from a non-human animal source, or human body fluids, cells, tissues, or organs that have had ex vivo contact with live non-human cells, tissues, or organs

[ASTM F2312-11]

\subsection{1 zygote}

fertilized egg 


\section{ANNEX A (INFORMATIVE) REGULATORY TERMS}

I Table A.1 - Regulatory terms 


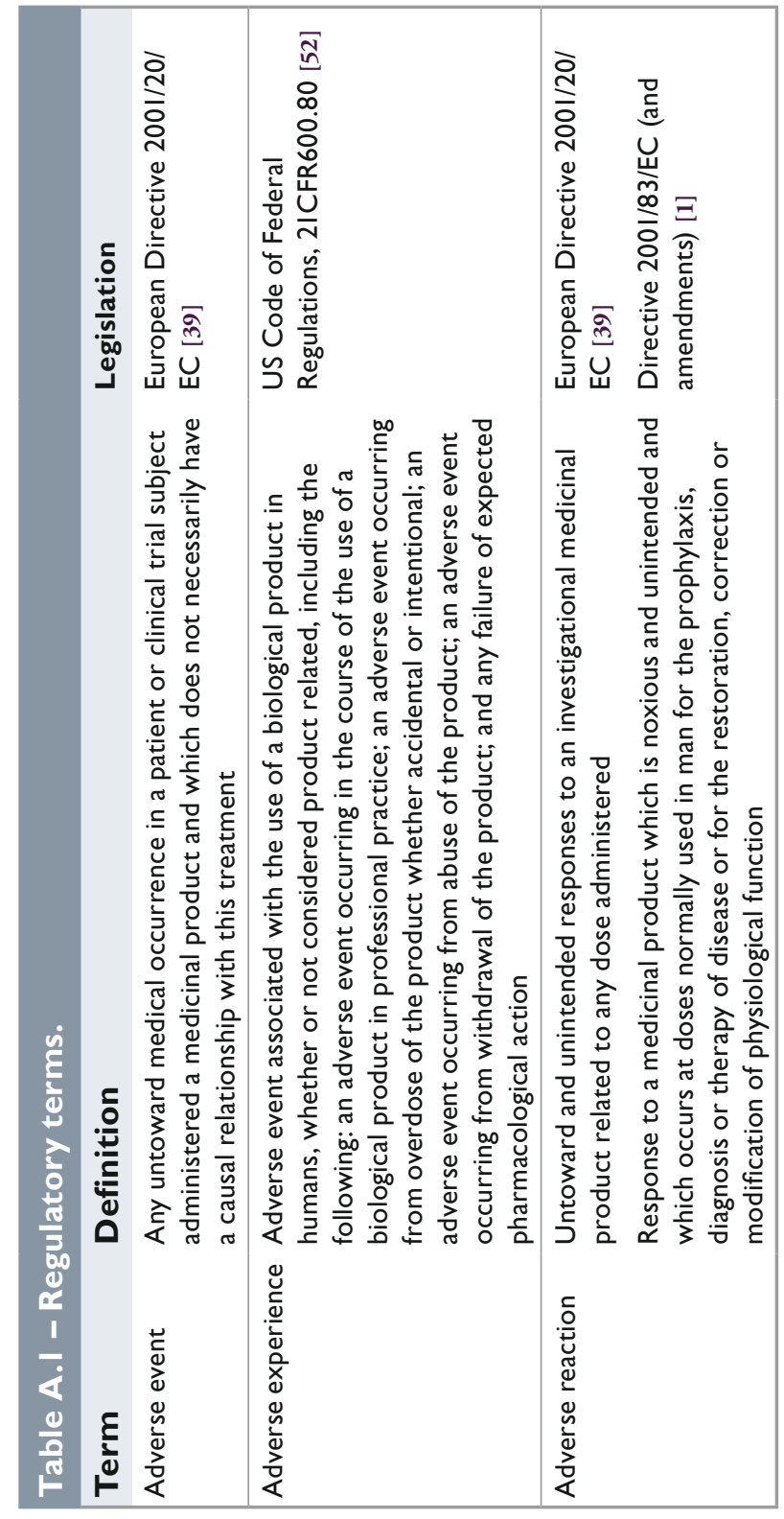




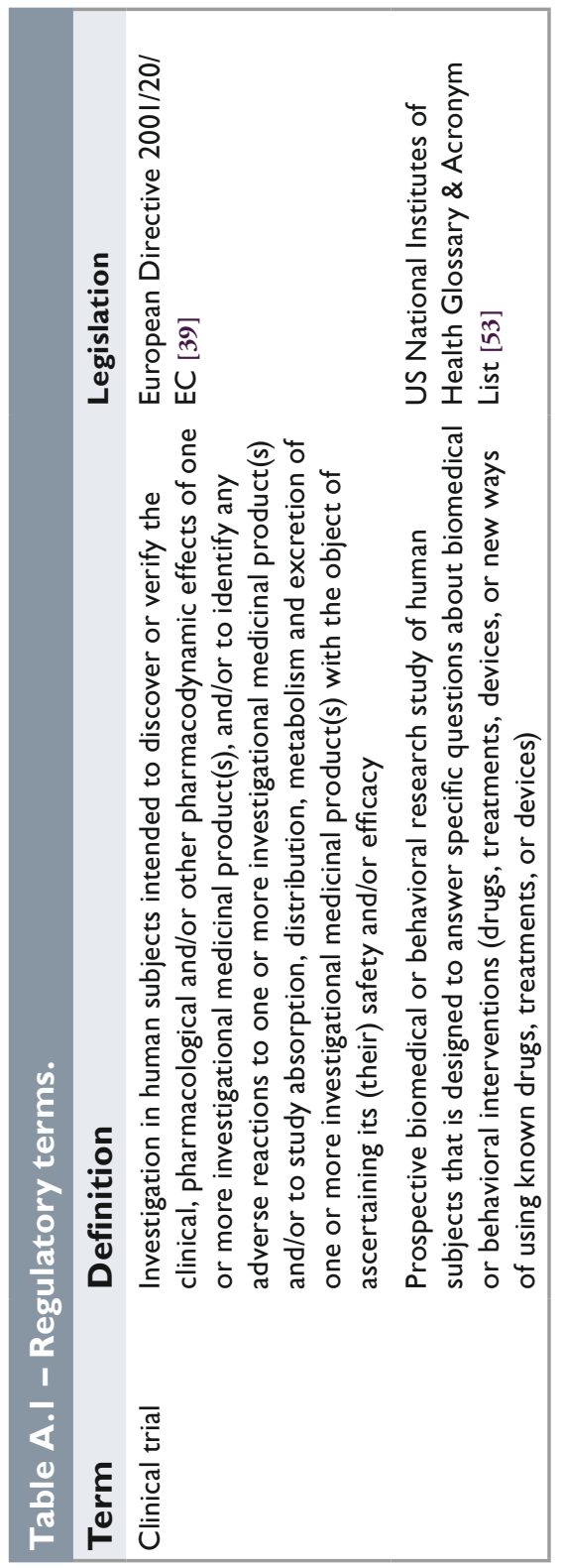



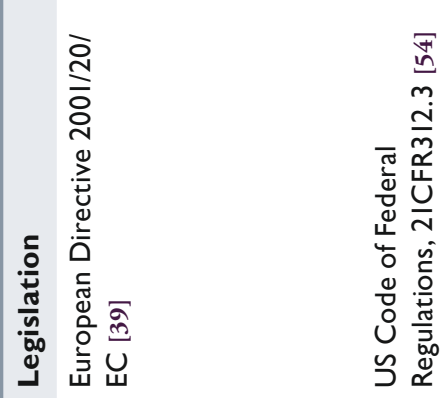

인

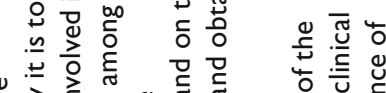
0.入 ฮ্ৰ

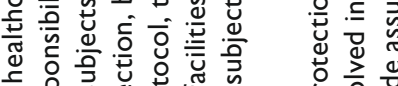

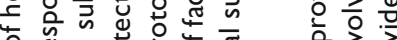

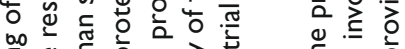
品

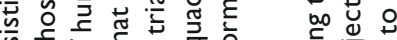

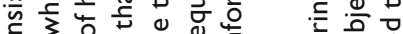

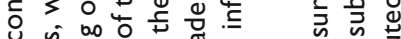
๑ิ

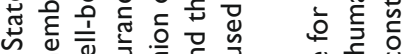

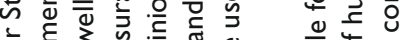

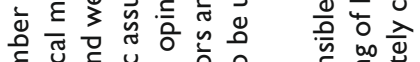

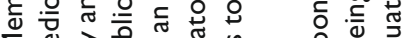

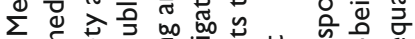
$\approx \stackrel{0}{\longleftarrow}$ 口. $\subseteq$ ठ .$\subseteq$ n

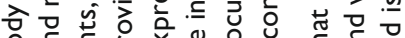

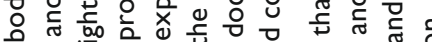
느의 0 i

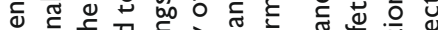

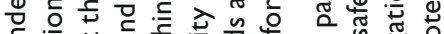

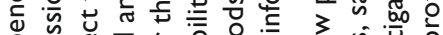

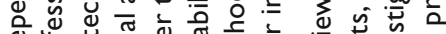

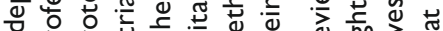

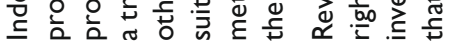




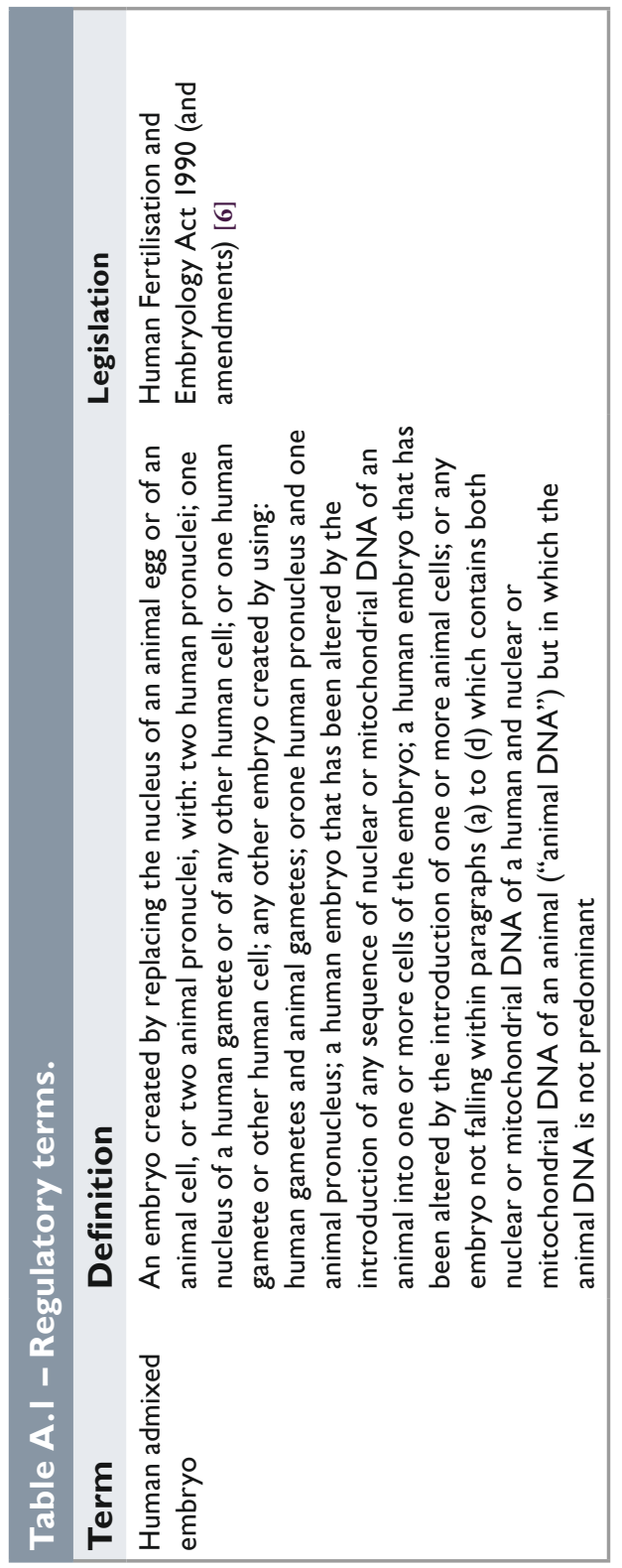




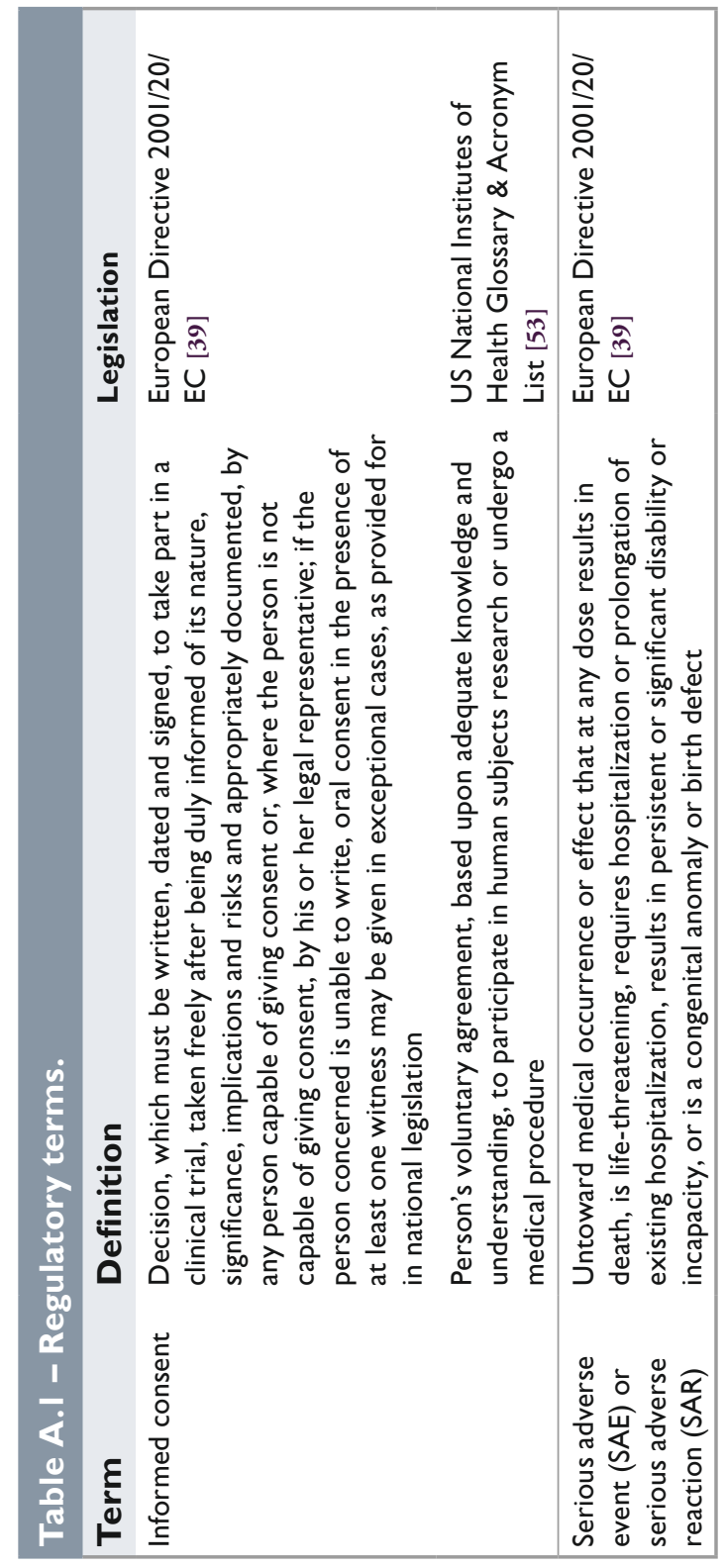




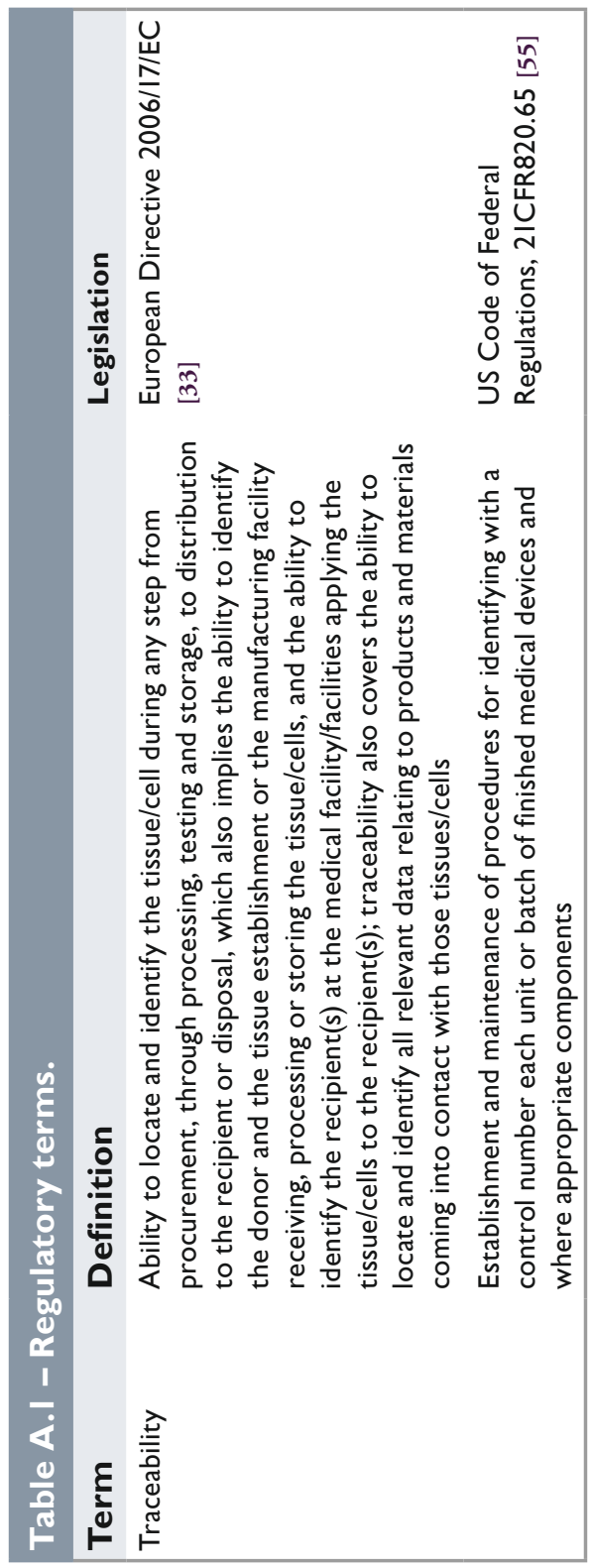




\section{ANNEX B (INFORMATIVE) FINANCE}

\section{B.1 angel investor}

specialist, independent investor that typically provides start-up capital to early stage companies

\section{B.2 cash burn rate}

measure of how rapidly a company spends its shareholders' capital

\section{B.3 cross licensing}

reciprocal agreement between two or more parties that confers rights to access and utilized named intellectual capital

\section{B.4 discount rate}

interest rate applied in discounted cash flow analysis to determine the time value of money, accounting for inflation and predicted returns from alternative investments

\section{B.5 discounted cash flow (DCF) analysis}

valuation technique that accounts for the time value of money, including inflation and predicted returns from alternative investments

\section{B.6 disruptive technology}

innovation that creates a new (and unexpected) market by applying a different set of values 


\section{B.7 initial public offering (IPO)}

transaction whereby a company offers shares of ownership, or equity, to investors through a market in order to raise capital

NOTE Thereafter, the shares can be publicly traded without any restrictions on ownership.

\section{B.8 internal rate of return (IRR)}

discount rate at which the net present value (NPV) of costs, negative cash flows become equal to the NPV, of benefits, positive cash flows, of a given investment

NOTE In other words, the point at which any profits generated by a company exceed the borrowing costs of capital used to provide the initial investment. Calculated through discounted cash flow (DCF) analysis.

\section{B.9 net present value (NPV)}

valuation methodology that analyses discounted cash flows to account for their present and future values

\section{B.10 parallel importing}

importing and sale of pharmaceutical products into jurisdictions other than those in which they were initially intended for sale, thus attempting to realize an arbitrage opportunity

\section{B.11 private equity}

investment in or acquisition of mature companies 


\section{B.12 small \& medium sized enterprise (SME)}

companies with headcount and either turnover or balance sheet total below certain limits

NOTE I A small enterprise is described as having a headcount of below 50 and a turnover of less than or equal to $€ 10000000$.

NOTE 2 A medium enterprise is described as having a headcount of below 250 and a turnover of lower than or equal to $€ 50000000$.

\section{B.13 venture capital}

investment in or acquisition of early stage companies [US Food And Drug Administration's Guidance for Industry Process Validation: General Principles and Practices [30]] 


\section{BIBLIOGRAPHY}

\section{Standards publications}

For dated references, only the edition cited applies. For undated references, the latest edition of the referenced document (including any amendments) applies.

- ASTM F2312-11, Standard terminology relating to tissue engineered medical products

- BS EN ISO 10993-6:2009, Biological evaluation of medical devices - Part 6: Tests for local effects after implantation

- BS EN ISO 14644-1:1999, Cleanrooms and associated controlled environments - Part 1: Classification of air cleanliness

- BS EN ISO 14971:2009, Medical devices - Application of risk management to medical devices

- ISO/IEC Guide 51:1999, Safety aspects - Guidelines for their inclusion in standards

\section{Other publications}

1 EUROPEAN COMMUNITIES. Directive 2001/83/EC of the European Parliament and of the Council of 6 November 2001 on the Community code relating to medicinal products for human use as amended by European Directives 2002/98/ EC, 2003/63/EC, 2004/24/EC, 2004/27/EC, 2008/29/EC, 2009/53/EC, 2009/120/EC, 2010/84/EU, 2011/62/EU and European Regulations No. 1901/2006 and No. 1394/2007 [5]. Luxembourg: Publications Office of the European Union.

2 EUROPEAN COMMUNITIES. Directive 2004/23/EC of the European Parliament and of the Council of 31 March 2004 on setting standards of quality and safety for the donation, procurement, testing, processing, preservation, 
storage and distribution of human tissues and cells.

Luxembourg: Publications Office of the European Union, 2004 .

3 GREAT BRITAIN. Human Tissue (Quality and Safety for Human Application) Regulations 2007. London: The Stationery Office. Statutory Instrument 2007 No. 1523.

4 EUROPEAN COMMUNITIES. Directive 2010/45/EU of the European Parliament and of the Council of 7 July 2010 on standards of quality and safety of human organs intended for transplantation. Luxembourg: Publications Office of the European Union, 2010.

5 EUROPEAN COMMUNITIES. Regulation (EC) No. 1394/2007 of the European Parliament and of the Council of 13 November 2007 on advanced therapy medicinal products and amending Directive 2001/83/EC [1] and Regulation (EC) No. 726/2004 [23]. Luxembourg: Publications Office of the European Union, 2007.

6 GREAT BRITAIN. Human Fertilisation and Embryology Act 1990 (and amendments). London: The Stationery Office.

7 GREAT BRITAIN. Human Tissue Act 2004. London: The Stationery Office.

8 GREAT BRITAIN. Human Tissue (Scotland) Act 2006 (and amendments). London: The Stationery Office.

9 EUROPEAN COMMISSION. Eudralex: The Rules Governing Medicinal Products in the European Union Volume 4: Good Manufacturing Practice - Medicinal Products for Human and Veterinary use - Part II: Basic Requirements for Active Substances used as Starting Materials. Brussels: European Commission, January 2010.

10 EUROPEAN COMMUNITIES. Council Directive 90/385/ EEC of 20 June 1990 on the approximation of the laws of the Member States relating to active implantable medical devices 
as amended by European Directives 93/42/EEC [34], 93/68/ EEC and 2007/47/EC and European Regulation No. 1882/2003. Luxembourg: Publications Office of the European Union.

11 INTERNATIONAL CONFERENCE ON HARMONISATION OF TECHNICAL REQUIREMENTS FOR REGISTRATION OF PHARMACEUTICALS FOR HUMAN USE (ICH). ICH Harmonised Tripartite Guideline Q7. Good Manufacturing Practice for Active Pharmaceutical Ingredients. Geneva: ICH, November 2000.

12 EUROPEAN COMMISSION. Eudralex: The Rules Governing Medicinal Products in the European Union Volume 9A: Guidelines on Pharmacovigilance for Medicinal Products for Human Use. Brussels: European Commission, September 2008.

13 UNITED KINGDOM STEM CELL BANK (UKSCB). Code of Practice for the Use of Human Stem Cell Lines. Version 5. Potters Bar: UKSCB, April 2010.

14 HUMAN FERTILISATION AND EMBRYOLOGY AUTHORITY (HFEA). Hybrids and Chimeras - A report on the findings of the consultation. London: HFEA, October 2007.

15 NETCORD-FACT. International Standards for Cord Blood Collection, Processing, and Release for Administration. 4th edition. Omaha, NE: FACT, January 2010.

16 EUROPEAN COMMISSION. Eudralex: The Rules Governing Medicinal Products in the European Union Volume 4: Good Manufacturing Practice - Medicinal Products for Human and Veterinary Use - Glossary. Brussels: European Commission, October 2005.

17 WILLIAMS, D.F. The Williams Dictionary of Biomaterials. Liverpool: Liverpool University Press, 1999. 
18 GREAT BRITAIN. The Control of Substances Hazardous to Health Regulations 2002. London: The Stationery Office. Statutory Instrument 2002 No. 2677.

19 EUROPEAN MEDICINES AGENCY (EMA). Committee for medicinal products for human use (CHMP). Guideline on similar biological medicinal products containing biotechnology-derived proteins as active substance: Quality issues. London: EMA, February 2006.

20 UNITED STATES NATIONAL INSTITUTE OF HEALTH (US NIH). Stem Cell Information. Glossary. Bethesda, MD: US NIH, 2010. http://stemcells.nih.gov/info/ glossary

21 INTERNATIONAL CONFERENCE ON HARMONISATION OF TECHNICAL REQUIREMENTS FOR REGISTRATION OF PHARMACEUTICALS FOR HUMAN USE (ICH). ICH Harmonised Tripartite Guideline Q5D. Derivation and characterisation of cell substrates used for production of biotechnological/biological products. Geneva: ICH, July 1997.

22 EUROPEAN MEDICINES AGENCY (EMA). Committee for medicinal products for human use (CHMP). Guideline on Human Cell-Based Medicinal Products. London: EMA, May 2008.

23 EUROPEAN COMMUNITIES. Regulation (EC) No. $726 / 2004$ of the European Parliament and of the Council of 31 March 2004 laying down Community procedures for the authorisation and supervision of medicinal products for human and veterinary use and establishing a European Medicines Agency as amended by European Regulation Nos 1901/2006, 1394/2007, 219/2009, 470/2009 and 1235/2010. Luxembourg: Publications Office of the European Union. 
24 EUROPEAN MEDICINES AGENCY (EMA). Committee for medicinal products for human use (CHMP). Guideline on safety and efficacy follow-up - Risk management of advanced therapy medicinal products. London: EMA, November 2008.

25 UNITED STATES. 21CFR312.42. Code of Federal Regulations (CFR) - Title 21: Food and drugs - Chapter I: Food and drug administration department of health and human services - Subchapter D: Drugs for human use - Part 312: Investigational new drug application - Subpart C: Administrative actions - Section 312.42: Clinical holds and requests for modification. Washington, DC: US Government Printing Office, April 2010.

26 EUROPEAN COMMISSION. Eudralex: The Rules Governing Medicinal Products in the European Union Volume 4: Good Manufacturing Practice - Medicinal Products for Human and Veterinary Use - Annex 2:

Manufacture of Biological Medicinal Substances and Products for Human Use. Second consultation draft issued 9 April 2010. Brussels: European Commission, April 2010.

27 UNITED STATES FOOD AND DRUG

ADMINISTRATION (FDA). Guidance for Industry - Sterile Drug Products Produced by Aseptic Processing - Current Good Manufacturing Practice. Silver Spring, MD: FDA, September 2004.

28 INTERNATIONAL CONFERENCE ON HARMONISATION OF TECHNICAL REQUIREMENTS FOR REGISTRATION OF PHARMACEUTICALS FOR HUMAN USE (ICH). ICH Harmonised Tripartite Guideline Q5E. Comparability of biotechnological/biological products subject to changes in their manufacturing process. Geneva: ICH, November 2004.

29 EUROPEAN COMMUNITIES. Council Directive 90/219/ EEC of 23 April 1990 on the contained use of genetically modified microorganisms as amended by European Directives 
98/81/EC, 2001/204/EC, 2005/174/EC and European Regulation No. 1882/2003. Luxembourg: Publications Office of the European Union.

30 UNITED STATES FOOD AND DRUG

ADMINISTRATION (FDA). Guidance for Industry Process Validation: General Principles and Practices - Current Good Manufacturing Practice. Revision 1. Silver Spring, MD: FDA, January 2011.

31 Dorland's Pocket Medical Dictionary. 28th edition. Philadelphia: Saunders, 2008.

32 DRUMMOND, M.F., B.J. O'BRIEN, M.J. SCULPHER, G.L. STODDART and G.W. TORRANCE. Methods for the Economic Evaluation of Health Care Programmes. 3rd edition. Oxford: Oxford University Press, 2005.

33 EUROPEAN COMMUNITIES. Directive 2006/17/EC of the European Parliament and of the Council of 8 February 2006 implementing Directive 2004/23/EC [2] of the European Parliament and of the Council as regards certain technical requirements for the donation, procurement and testing of human tissues and cells. Luxembourg: Publications Office of the European Union, 2006.

34 Larousse Dictionary of Science and Technology. Edinburgh: Larousse, 1995.

35 RUSSO, V.E.A., R.A. MARTIENSSEN and R.A. RIGGS, eds. Epigenetic mechanisms of gene regulation. Plainview, NY: Cold Spring Harbor Laboratory Press, 1996.

INTERNATIONAL CONFERENCE ON HARMONISATION OF TECHNICAL REQUIREMENTS FOR REGISTRATION OF PHARMACEUTICALS FOR HUMAN USE (ICH). ICH Harmonised Tripartite Guideline Q1A(R2). Stability Testing of New Drug Substances and Products. Second Revision. Geneva: ICH, February 2003. 
37 EUROPEAN COMMUNITIES. Directive 2001/18/EC of the European Parliament and of the Council of 12 March 2001 on the deliberate release into the environment of genetically modified organisms and repealing Council Directive 90/220/EEC and as amended by European Regulations No. 1829/2003 and No. 1830/2003 and European Directive 2008/27. Luxembourg: Publications Office of the European Union.

38 HUMAN TISSUE AUTHORITY (HTA). Code of practice 1 - Consent. London: HTA, September 2009.

39 EUROPEAN COMMUNITIES. Directive 2001/20/EC of the European Parliament and of the Council of 4 April 2001 on the approximation of the laws, regulations and administrative provisions of the Member States relating to the implementation of good clinical practice in the conduct of clinical trials on medicinal products for human use as amended by Regulation (EC) No. 1901/2006. Luxembourg: Publications Office of the European Union.

40 EUROPEAN COMMUNITIES. Council Directive 93/42/ EEC of 14 June 1993 concerning medical devices as amended by European Directives 98/79/EC, 2000/70/EC, 2001/104/EC, 2007/47/EC and European Regulation No. 1882/2003. Luxembourg: Publications Office of the European Union.

41 UNITED STATES. 21CFR1271.3. Code of Federal Regulations (CFR) - Title 21: Food and drugs - Chapter I: Food and drug administration department of health and human services - Subchapter L: Regulations under certain other acts administered by the food and drug administration - Part 1271: Human cells, tissues, and cellular and tissuebased products - Subpart A: General provisions Section 1271.3: How does FDA define important terms in this part? Washington, DC: US Government Printing Office, April 2010. 
42 INTERNATIONAL CONFERENCE ON

HARMONISATION OF TECHNICAL

REQUIREMENTS FOR REGISTRATION OF

PHARMACEUTICALS FOR HUMAN USE (ICH). ICH

Harmonised Tripartite Guideline Q10. Pharmaceutical

Quality System. Geneva: ICH, June 2008.

43 DEPARTMENT OF HEALTH (DH) AND FOOD

STANDARDS AGENCY (FSA). Committees on Toxicity, Mutagenicity, Carcinogenicity of Chemicals in Food, Consumer Products and the Environment. Annual Report 2006. London: The Stationery Office, July 2007.

44 WORLD HEALTH ORGANIZATION (WHO). The Importance of Pharmacovigilance: Safety Monitoring of Medicinal Products. Geneva: WHO, 2002.

45 INTERNATIONAL CONFERENCE ON HARMONISATION OF TECHNICAL REQUIREMENTS FOR REGISTRATION OF PHARMACEUTICALS FOR HUMAN USE (ICH). ICH Harmonised Tripartite Guideline Q6B. Specifications: Test Procedures and Acceptance Criteria for Biotechnological/ Biological Products. Geneva: ICH, March 1999.

46 INTERNATIONAL CONFERENCE ON HARMONISATION OF TECHNICAL REQUIREMENTS FOR REGISTRATION OF PHARMACEUTICALS FOR HUMAN USE (ICH). ICH Harmonised Tripartite Guideline Q8(R2). Pharmaceutical development. Geneva: ICH, August 2009.

47 DODGE, Y. ed. The Oxford Dictionary of Statistical Terms. Oxford: Oxford University Press, 2003.

48 INTERNATIONAL CONFERENCE ON HARMONISATION OF TECHNICAL REQUIREMENTS FOR REGISTRATION OF PHARMACEUTICALS FOR HUMAN USE (ICH). ICH 
Harmonised Tripartite Guideline Q9. Quality Risk Management. Geneva: ICH, November 2005.

49 EUROPEAN COMMISSION. Eudralex: The Rules Governing Medicinal Products in the European Union Volume 4: EU Guidelines to Good Manufacturing Practice - Medicinal Products for Human and Veterinary use - Part I: Basic Requirements for Medicinal Products - Chapter 1: Quality Management. Brussels: European Commission, February 2008.

50 MASON, C. and P. DUNNILL. A brief definition of regenerative medicine. Regenerative Medicine, 2008, 3(1), $1-5$.

51 INTERNATIONAL CONFERENCE ON HARMONISATION OF TECHNICAL REQUIREMENTS FOR REGISTRATION OF PHARMACEUTICALS FOR HUMAN USE (ICH). ICH Harmonised Tripartite Guideline E6(R1). Guideline for Good Clinical Practice. Geneva: ICH, June 1996.

52 UNITED STATES. 21CFR600.80. Code of Federal Regulations (CFR) - Title 21: Food and drugs - Chapter I: Food and drug administration department of health and human services - Subchapter F: Biologics - Part 600: Biological products: General - Subpart D: Reporting of adverse Experiences - Section 600.80: Postmarketing reporting of adverse experience. Washington, DC: US Government Printing Office, April 2011.

53 UNITED STATES NATIONAL INSTITUTES OF HEALTH (NIH) OFFICE OF EXTRAMURAL RESEARCH. Glossary \& Acronym List. Geneva: ICH, 26 May 2011.

54 UNITED STATES. 21CFR312.3. Code of Federal Regulations (CFR) - Title 21: Food and drugs - Chapter I: Food and drug administration department of health and human services - Subchapter D: Drugs for human use - Part 
312: Investigational new drug application - Subpart A:

General provisions - Section 312.3: Definitions and interpretations. Washington, DC: US Government Printing Office, April 2010.

55 UNITED STATES. 21CFR820.65. Code of Federal Regulations (CFR) - Title 21: Food and drugs - Chapter I: Food and drug administration department of health and human services - Subchapter H: Medical devices - Part 820: Quality system regulation - Subpart F: Identification and traceability - Section 820.65: Traceability. Washington, DC: US Government Printing Office, April 2010. 


\section{Useful websites}

ASTM International

www.astm.org

EU pharmaceutical information http://ec.europa.eu/health/index_en.htm

EU legislation information http://europa.eu/

- European Medicines Agency (EMA) www.ema.europa.eu

International Society for Cellular Therapy (ISCT) www.celltherapysociety.org

US National Institutes of Health (NIH) www.nih.gov

UK Medicines and Healthcare products Regulatory Agency (MHRA) www.mhra.gov.uk

- UK Department of Health www.dh.gov.uk

- UK Department of Health/Medical Research Council online clinical trials guide www.ct-toolkit.ac.uk

- UK Human Fertilisation and Embryology Authority www.hfea.gov.uk

- UK Human Tissue Authority www.hta.gov.uk

- UK National Blood Service www.blood.co.uk

UK Stem Cell Bank www.ukstemcellbank.org.uk

US Food and Drug Administration www.fda.gov

The United States Pharmacopeia Convention (USP) www.usp.org 


\section{INDEX}

This index lists all terms, as well as any alternative terms, referred to in this PAS.

acceptance criteria, 2.1

active implantable medical device, $\mathbf{2 . 2}$ active medical device, $\mathbf{2 . 3}$ active pharmaceutical ingredient (API), see active substance active substance, $\mathbf{2 . 4}$ active surveillance, $\mathbf{2 . 5}$ admixed embryo, $\mathbf{2 . 6}$ adult stem cell, 2.7 advanced therapy medicinal product, 2.8

adventitious, 2.9 adventitious agent, $\mathbf{2 . 1 0}$ adverse event, 2.11 adverse event reporting, $\mathbf{2 . 1 2}$ adverse experience, see adverse event

adverse reaction, 2.13

allogeneic, 2.14

allograft, 2.15

ancillary material, $\mathbf{2 . 1 6}$

angel investor, B.1

animal chimera embryo, 2.17 apoptosis, $\mathbf{2 . 1 8}$

arm, 2.19

aseptic technique, $\mathbf{2 . 2 0}$

asymmetric cell division, 2.21

audit, 2.22

autograft, 2.23

autologous, 2.24

baseline, 2.25

batch (or lot), 2.26

batch (or lot) number, 2.27

bioactive agent, $\mathbf{2 . 2 8}$

bioaesthetics, 2.29 bioburden, 2.30

biocompatibility, 2.31

biodistribution, 2.32

biologic, see biological medicinal product

biological agent, 2.33

biological medicinal product, 2.34

biological substance, $\mathbf{2 . 3 5}$

biomarker, 2.36

biomaterial, 2.37

biomolecule, $\mathbf{2 . 3 8}$

bioprocessing, 2.39

bioreactor, 2.40

biosimilar, 2.41

blastocyst, 2.42

blastomere, $\mathbf{2 . 4 3}$

cancer immunotherapy, see cancer vaccine

cancer vaccine, $\mathbf{2 . 4 4}$

cash burn rate, B. 2

cell authenticity, 2.45

cell bank, 2.46

cell-based medicinal product

(CBMP), 2.47

cell culture, 2.48

cell division, 2.49

cell expansion, $\mathbf{2 . 5 0}$

cell line, $\mathbf{2 . 5 1}$

cell migration, 2.52

cell morphology, 2.53

cell selection, $\mathbf{2 . 5 4}$

cell surface marker, 2.55

cell therapy, $\mathbf{2 . 5 6}$

cell therapy product, $\mathbf{2 . 5 7}$

cell viability, 2.58 
cellular active substance, 2.59

cellular starting material, $\mathbf{2 . 6 0}$

centralized authorization proce-

dure, 2.61

centralized procedure, see centralized authorization procedure

chief investigator, $\mathbf{2 . 6 2}$

chimera, 2.63

chimerism, 2.64

clean facility, see cleanroom

cleanroom, 2.65

clinical equivalent, $\mathbf{2 . 6 6}$

clinical follow-up, 2.67

clinical hold, $\mathbf{2 . 6 8}$

clinical investigator, 2.69

clinical research organization

(CRO), 2.70

clinical translation, $\mathbf{2 . 7 1}$

clinical trial, 2.72

clone, 2.73

cloning, 2.74

clonogenic cell, 2.75

closed system, $\mathbf{2 . 7 6}$

colony forming unit (CFU), 2.77

combination cell therapy, $\mathbf{2 . 7 8}$

combination product, $\mathbf{2 . 7 9}$

combined advanced therapy

medicinal product (combined

ATMP), $\mathbf{2 . 8 0}$

comparability, $\mathbf{2 . 8 1}$

comparable, $\mathbf{2 . 8 2}$

comparative genomic hybridization

(CGH), 2.83

competent authority, $\mathbf{2 . 8 4}$

conditioning, 2.85

confounding factor, 2.86

contained use, $\mathbf{2 . 8 7}$

contamination, $\mathbf{2 . 8 8}$

contaminant, $\mathbf{2 . 8 9}$

continued process verification,

2.90 continuous cell line, $\mathbf{2 . 9 1}$

contract manufacturing organiza-

tion (CMO), 2.92

contract research organization

(contract RO), 2.93

control, 2.94

controlled trial, 2.95

cord blood, 2.96

cord blood stem cell, 2.97

cord blood transplantation, 2.98

cosmesis, 2.99

cost benefit analysis, $\mathbf{2 . 1 0 0}$

cross-contamination, $\mathbf{2 . 1 0 1}$

cross licensing, B.3

cryopreservation, $\mathbf{2 . 1 0 2}$

cryoprotectant, $\mathbf{2 . 1 0 3}$

cryoprotection, $\mathbf{2 . 1 0 4}$

culture medium, 2.105

current Good Cell Culture Practice (cGCCP), see Good Cell Culture

Practice (GCCP)

current Good Clinical Practice

(cGCP), see Good Clinical

Practice (GCP)

current Good Laboratory Practice

(cGLP), see Good Laboratory

Practice (GLP)

current Good Manufacturing

Practice (cGMP), see Good

Manufacturing Practice (GMP)

current Good Tissue Practice

(cGTP), see Good Tissue Practice

(GTP)

cytokine, 2.106

cytoplasmic hybrid embryos

(cybrid), 2.107

de-differentiation, $\mathbf{2 . 1 0 8}$

differentiation, 2.109

defined medium, $\mathbf{2 . 1 1 0}$

direct use, 2.111 
discount rate, B.4

discounted cash flow (DCF)

analysis, B.5

disruptive technology, B.6

DNA fingerprinting, see DNA

profiling

DNA profiling, $\mathbf{2 . 1 1 2}$

DNA short tandem repeat profiling (DNA STR profiling), $\mathbf{2 . 1 1 3}$

donation, 2.114

donor, 2.115

donor selection, $\mathbf{2 . 1 1 6}$

dose, 2.117

dose finding study, $\mathbf{2 . 1 1 8}$

double-blind trial, 2.119

downstream processing, $\mathbf{2 . 1 2 0}$

drug substance, see active

substance

efficacy follow-up, $\mathbf{2 . 1 2 1}$

eligibility criteria, $\mathbf{2 . 1 2 2}$

embryonic stem cell, $\mathbf{2 . 1 2 3}$

embryonic stem cell line, $\mathbf{2 . 1 2 4}$

encapsulation, $\mathbf{2 . 1 2 5}$

endpoint, 2.126

engineered cells and/or tissues,

2.127

engraftment, $\mathbf{2 . 1 2 8}$

epigenetic, 2.129

ethics committee, $\mathbf{2 . 1 3 0}$

ex vivo, 2.131

excipient, 2.132

extracellular matrix (ECM), $\mathbf{2 . 1 3 3}$

extracorporeal, 2.134

false negative, $\mathbf{2 . 1 3 5}$

false positive, $\mathbf{2 . 1 3 6}$

feeder cell, 2.137

fetal stem cell, $\mathbf{2 . 1 3 8}$

finite cell line, 2.139

flow cytometry, 2.140 fluorescence activated cell sorting

(FACS), 2.141

gene expression profile (transcrip-

tome), $\mathbf{2 . 1 4 2}$

gene therapy, $\mathbf{2 . 1 4 3}$

gene therapy medicinal product,

2.144

gene transfer, 2.145

genetic locus, $\mathbf{2 . 1 4 6}$

genetically modified organism

(GMO), 2.147

genotype, $\mathbf{2 . 1 4 8}$

Good Cell Culture Practice

(GCCP), 2.149

Good Clinical Practice (GCP),

2.150

Good Laboratory Practice (GLP),

2.151

Good Manufacturing Practice

(GMP), 2.152

Good Tissue Practice (GTP),

2.153

graft versus host disease (GVHD),

2.154

growth factor, 2.155

haemocytometer, 2.156

haematopoiesis, 2.157

haematopoietic stem cell (HSC),

2.158

Hayflick limit, 2.159

heterologous use, 2.160

heterotopic, $\mathbf{2 . 1 6 1}$

histocompatibility, $\mathbf{2 . 1 6 2}$

histology, 2.163

homograft, see allograft

homologous use, 2.164

homotopic, 2.165

human chimera embryo, $\mathbf{2 . 1 6 6}$

human leucocyte-associated

antigen (HLA), 2.167 
hybrid embryo, see admixed embryo

immobilization, 2.168

immortal, 2.169

immunocytochemistry, $\mathbf{2 . 1 7 0}$

immunogenicity, 2.171

immunohistochemistry, $\mathbf{2 . 1 7 2}$

immunological rejection, 2.173

immunomodulation, 2.174

immunotherapy, $\mathbf{2 . 1 7 5}$

impurity, 2.176

in vitro, 2.177

in vivo, $\mathbf{2 . 1 7 8}$

in-process control, 2.179

inclusion and exclusion criteria, see eligibility criteria

induced pluripotent stem cell (iPS cell), $\mathbf{2 . 1 8 0}$

informed consent, $\mathbf{2 . 1 8 1}$

initial public offering (IPO), B.7

inner cell mass (ICM), $\mathbf{2 . 1 8 2}$

intermediate, $\mathbf{2 . 1 8 3}$

internal rate of return (IRR), B.8

investigational medicinal product

(IMP), 2.184

investigational new drug (IND),

see investigational medicinal

product (IMP)

karyotyping, 2.185

magnetic-based cell sorting, $\mathbf{2 . 1 8 6}$ major histocompatibility complex (MHC), 2.187

manufacture, $\mathbf{2 . 1 8 8}$

marketing authorization, 2.189

marrow stromal cell, 2.190

master cell bank (MCB), 2.191

medical device, $\mathbf{2 . 1 9 2}$

medicinal product, 2.193 mesenchymal stem cell, 2.194

mesenchymal stromal stem cells, see mesenchymal stem cell

microarray, 2.195

minimal manipulation, 2.196

minor histocompatibility antigen

(mH antigen), 2.197

morula, 2.198

multipotent, 2.199

mycoplasma, $\mathbf{2 . 2 0 0}$

national competent authority

(NCA), see competent authority necrosis, 2.201

net present value (NPV), B.9

non-clinical study, $\mathbf{2 . 2 0 2}$

non-interventional trial, $\mathbf{2 . 2 0 3}$

observational trial, 2.204

off-label use, 2.205

open-label trial, 2.206

organ, 2.207

orphan drug, 2.208

orthotopic, see homotopic

parallel group, 2.209

parallel importing, B.10

parthenogenesis, $\mathbf{2 . 2 1 0}$

parthenogenetic stem cell line,

2.211

passage, $\mathbf{2 . 2 1 2}$

passage number, $\mathbf{2 . 2 1 3}$

passive surveillance, $\mathbf{2 . 2 1 4}$

pathogen, 2.215

performance indicator, 2.216

performance metrics, see perfor-

mance indicator

permitted embryo, $\mathbf{2 . 2 1 7}$

pharmacodynamics, $\mathbf{2 . 2 1 8}$

pharmacokinetics, 2.219

pharmacology, $\mathbf{2 . 2 2 0}$ 
pharmacovigilance, 2.221

phase I trial, 2.222

phase II trial, 2.223

phase III trial, $\mathbf{2 . 2 2 4}$

phase IV trial, 2.225

phenotype, $\mathbf{2 . 2 2 6}$

placebo, 2.227

placebo controlled trial, 2.228

placing on the market, $\mathbf{2 . 2 2 9}$

plasmid, 2.230

plating efficiency, $\mathbf{2 . 2 3 1}$

pluripotent, $\mathbf{2 . 2 3 2}$

polymerase chain reaction (PCR),

2.233

population doubling, 2.234

porosity, 2.235

post-authorization safety study,

\subsection{6}

post-market surveillance, $\mathbf{2 . 2 3 7}$

potency, 2.238

power of study, 2.239

preclinical study, $\mathbf{2 . 2 4 0}$

precursor cell, $\mathbf{2 . 2 4 1}$

preservation, $\mathbf{2 . 2 4 2}$

primary cell culture, $\mathbf{2 . 2 4 3}$

principal investigator, 2.244

private equity, B.11

process analytical technology

(PAT), 2.245

progenitor cell, 2.246

proliferation, 2.247

prospective trial, 2.248

protein expression, 2.249

protocol, 2.250

provenance, 2.251

purity, 2.252

qualification, 2.253

qualified person (QP), $\mathbf{2 . 2 5 4}$

qualified person responsible for

pharmacovigilance (QPPV), 2.255 quality, 2.256

quality assurance (QA), $\mathbf{2 . 2 5 7}$

quality by design (QbD), 2.258

quality control (QC), 2.259

quality system, $\mathbf{2 . 2 6 0}$

quiescence, $\mathbf{2 . 2 6 1}$

randomized trial, 2.262

raw material, 2.263

real time release testing (RTR test-

ing), 2.264

recall, 2.265

regenerative medicine, $\mathbf{2 . 2 6 6}$

release criteria, $\mathbf{2 . 2 6 7}$

reproductive cloning, $\mathbf{2 . 2 6 8}$

reprogramming, 2.269

retrospective trial, $\mathbf{2 . 2 7 0}$

risk, 2.271

risk analysis, 2.272

risk management, $\mathbf{2 . 2 7 3}$

safety, 2.274

safety follow-up, 2.275

same surgical procedure, $\mathbf{2 . 2 7 6}$

scaffold, 2.277

scale out (or scale horizontally),

2.278

scale up (or scale vertically), 2.279

seeding density, $\mathbf{2 . 2 8 0}$

self-renewal, $\mathbf{2 . 2 8 1}$

senescence, $\mathbf{2 . 2 8 2}$

sensitivity, $\mathbf{2 . 2 8 3}$

serious adverse event (SAE), $\mathbf{2 . 2 8 4}$

serious adverse reaction (SAR),

2.285

sham procedure, $\mathbf{2 . 2 8 6}$

side effect, $\mathbf{2 . 2 8 7}$

significance, $\mathbf{2 . 2 8 8}$

similar biological medicinal prod-

uct, see biosimilar

single-blind trial, 2.289 
small and medium sized enterprise (SME), B.12

somatic cell, 2.290

somatic cell nuclear transfer

(SCNT), 2.291

somatic cell therapy medicinal

product, 2.292

somatic stem cell, see adult stem cell

specification, 2.293

specificity, 2.294

stability testing, $\mathbf{2 . 2 9 5}$

standard operating procedure

(SOP), 2.296

starting material, 2.297

state of control, 2.298

stem cell, 2.299

stem cell line, $\mathbf{2 . 3 0 0}$

sterile, 2.301

stromal cells, 2.302

stromal stem cell, see adult stem

cell

subject, 2.303

substantial manipulation, $\mathbf{2 . 3 0 4}$

syngeneic, $\mathbf{2 . 3 0 5}$

therapeutic cloning, 2.306

therapeutic equivalent, see clinical equivalent

therapeutic immunosuppression,

\subsection{7}

therapy, $\mathbf{2 . 3 0 8}$

tissue, 2.309

tissue bank, 2.310

tissue engineered product, 2.311

tissue engineering, $\mathbf{2 . 3 1 2}$

tissue establishment, $\mathbf{2 . 3 1 3}$

tissue typing, $\mathbf{2 . 3 1 4}$ toxicology, 2.315

totipotent, 2.316

traceability, 2.317

transduced cells, see gene transfer transgenic, $\mathbf{2 . 3 1 8}$

transgenic human embryo, 2.319

translation, $\mathbf{2 . 3 2 0}$

transplantation, $\mathbf{2 . 3 2 1}$

transplantation tolerance, $\mathbf{2 . 3 2 2}$

trophoblast, 2.323

tumour, 2.324

tumour-associated antigen, 2.325

tumorigenicity, $\mathbf{2 . 3 2 6}$

unexpected adverse reaction

(UAR), 2.327

unipotent, 2.328

upstream processing, 2.329

user requirement brief (URB),

2.330

user requirement specification

(URS), 2.331

validation, 2.332

vector, 2.333

venture capital, B.13

viral vector, 2.334

vitrification, 2.335

whole bioprocessing, 2.336

working cell bank (WCB), 2.337

xenogeneic, $\mathbf{2 . 3 3 8}$

xenograft, 2.339

xenotransplantation, $\mathbf{2 . 3 4 0}$

zygote, $\mathbf{2 . 3 4 1}$ 


\section{BRITISH STANDARDS INSTITUTION}

BSI is the independent national body responsible for preparing British Standards and other standards-related publications, information and services. It presents the UK view on standards in Europe and at the international level.

BSI is incorporated by Royal Charter. British Standards and other standardization products are published by BSI Standards Limited.

\section{Revisions}

British Standards and PASs are periodically updated by amendment or revision. Users of British Standards and PASs should make sure that they possess the latest amendments or editions.

It is the constant aim of BSI to improve the quality of our products and services. We would be grateful if anyone finding an inaccuracy or ambiguity while using British Standards would inform the Secretary of the technical committee responsible, the identity of which can be found on the inside front cover. Similary for PASs, please notify BSI Customer Services.

Tel: +44 (0)20 89969001 Fax: +44 (0)20 89967001

BSI offers BSI Subscribing Members an individual updating service called PLUS which ensures that subscribers automatically receive the latest editions of British Standards and PASs.

Tel: +44 (0)20 89967669 Fax: +44 (0)20 89967001

Email:plus@bsigroup.com

\section{Buying standards}

You may buy PDF and hard copy versions of standards directly using a credit card from the BSI Shop on the website www. bsigroup.com/shop.

In addition all orders for BSI, international and foreign standards publications can be addressed to BSI Customer Services.

Tel: +44 (0)2089969001 Fax: +44 (0)2089967001

Email: orders@bsigroup.com

In response to orders for international standards, BSI will supply the British Standard implementation of the relevant international standard, unless otherwise requested. 
Information on standards BSI provides a wide range of information on national, European and international standards through its Knowledge Centre.

Tel: +44 (0)208996 7004 Fax: +44 (0)20 89967005

Email: knowledgecentre@bsigroup.com

BSI Subscribing Members are kept up to date with standards developments and receive substantial discounts on the purchase price of standards. For details of these and other benefits contact Membership Administration.

Tel: +44 (0)208996 7002 Fax: +44 (0)20 89967001

Email: membership@bsigroup.com

Information regarding online access to British Standards and PASs via British Standards Online can be found at www.bsigroup.com/BSOL

Further information about British Standards is available on the BSI website at www.bsigroup.com/standards

\section{Copyright}

All the data, software and documentation set out in all British Standards and other BSI publications are the property of and copyrighted by BSI, or some person or entity that owns copyright in the information used (such as the international standardization bodies) has formally licensed such information to BSI for commercial publication and use. Except as permitted under the Copyright, Designs and Patents Act 1988 no extract may be reproduced, stored in a retrieval system or transmitted in any form or by any means - electronic, photocopying, recording or otherwise - without prior written permission from BSI. This does not preclude the free use, in the course of implementing the standard, of necessary details such as symbols, and size, type or grade designations. If these details are to be used for any other purpose than implementation then the prior written permission of BSI must be obtained. Details and advice can be obtained from the Copyright \& Licensing Department.

Tel: +44 (0)2089967070

Email: copyright@bsigroup.com

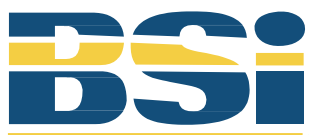

389 Chiswick High Road, London, W4 4AL, UK 


\section{REGENERATIVE MEDICINE}

\section{Audience}

The audience for Future Medicine titles consists of clinicians, research scientists, decision-makers and a range of professionals in the healthcare community.

\section{Submission}

We accept unsolicited manuscripts. If you are interested in submitting an article, or have any queries regarding article submission, please contact the Head of Commissioning directly (a.williams@ futuremedicine.com). For new article proposals, the Editor will require a brief article outline and working title in the first instance. We also have an active commissioning program whereby the Editor, under the advice of the Editorial Advisory Panel, solicits articles directly for publication.

\section{Peer review \& revision}

Once the manuscript has been received inhouse, it will be peer-reviewed (usually 2-3 weeks). Following peer review, 2 weeks is allowed for any revisions (suggested by the referees/Editor) to be made.

\section{In-house production}

Following acceptance of the revised manuscript, it will undergo production in-house. Authors will receive proofs of the article to approve before going to print, and will be asked to sign a copyright transfer form (except in cases where this is not possible, i.e., government employees in some countries).

\section{Article types}

- Reviews

- Primary research articles

- Perspectives

- Special reports

- Editorials

- Priority paper evaluations

- Conference scenes

- Company profile

For a more detailed desciption of each article type, please view our author guidelines at: www.futuremedicine.com

\section{Manuscript preparation \\ Spacing $\&$ headings}

Please use double line spacing throughout the manuscript. No more than four levels of subheading should be used to divide the text and should be clearly designated.

\section{Abbreviations}

Abbreviations should be defined on their first appearance, and in any table and figure footnotes. It is helpful if a separate list is provided of any abbreviations.

\section{Spelling}

US-preferred spelling will be used in the final publication.

\section{Figures, tables $\&$ boxes}

Future Medicine has a charge for the printing of color figures (i.e., each color page) in the print issue of the journal. We have no page charges and aim to keep our color charge to a minimum. The charge does not apply to the online version of articles, where all figures appear in color at no charge.

\section{Copyright}

If a figure, table or box has been published previously (even if you were the author), acknowledge the original source and submit written permission from the copyright holder to reproduce the material where necessary.

As the author of your manuscript, you are responsible for obtaining permissions to use material owned by others. Since the permission-seeking process can be remarkably time-consuming, it is wise to begin writing for permission as soon as possible.

Please send us photocopies of letters or forms granting you permission for the use of copyrighted material so that we can see that any special requirements with regard to wording and placement of credits are fulfilled. Keep the originals for your files. If payment is required for use of the figure, this should be covered by the author. 


\section{Key formatting points}

Please ensure your paper concurs with the following article format:

Title: concise, not more than 120 characters.

Author(s) names \& affiliations: including full name, address, phone \& fax numbers and e-mail.

Abstract/Summary: approximately 120 words. No references should be cited in the abstract.

Keywords: approximately 5-10 keywords for the review.

Body of the article: article content under relevant headings and subheadings.

Conclusion: analysis of the data presented in the review.

Future perspective: a speculative viewpoint on how the field will evolve in 5-10 years time.

Executive summary: bulleted summary points that illustrate the main topics or conclusions made under each of the main headings of the article.

\section{References:}

- Should be numerically listed in the reference section in the order that they occur in the text.

- Should appear as a number i.e., $[1,2]$ in the text.

- If websites or patents are included, please use a separate numbering system for them, i.e., start numbering website references at [101] and patents at [201] to allow the reader to distinguish between websites/patents and primary literature references both in the text and in the bibliography.

- Any references that are cited in figures/tables/boxes that do not appear in the text should be listed at the end of the reference list in the order they occur.

- Quote first six authors' names. If there are more than six, then quote first three et al.

The Future Medicine Endnote style can be downloaded from our website at: www.futuremedicine.com/page/authors.jsp

Reference annotations: please highlight $6-8$ references that are of particular significance to the subject and provide a brief (1-2 line) synopsis. Papers should be highlighted as one of the following:

" of interest

" $"$ of considerable interest

Figures/Tables/Boxes: Summary figures/tables/boxes are very useful, and we encourage their use in reviews/perspectives/special reports. The author should include illustrations and tables to condense and illustrate the information they wish to convey. Commentary that augments an article and could be viewed as 'standalone' should be included in a separate box. An example would be a summary of a particular trial or trial series, a case study summary or a series of terms explained. If any of the figures or tables used in the manuscript requires permission from the original publisher, it is the author's responsibility to obtain this. Figures must be in an editable format. 
“... a forum to address key advances and challenges in stem cells research and regenerative medicine..."

Improved healthcare has resulted in dramatic demographic changes in developed countries, causing an increase in the prevalence of diseases associated with aging. Many significant human diseases arising from the loss or dysfunction of specific cell types in the body, such as Parkinson's disease, diabetes and cancer, are becoming increasingly common.

Stem cell research and regenerative medicine offers unique opportunities for developing new therapeutic approaches to prevent and treat these debilitating and life-threatening diseases, and new ways to explore fundamental questions of biology. Gradually, the curative and regenerative potential that lies in harnessing stem cells and other regenerative strategies is being realized.

Regenerative Medicine (ISSN: 1746-075I) provides a forum to address the important challenges and advances in stem cell research and regenerative medicine, delivering this essential information in concise, clear and attractive article formats - vital to an increasingly time-constrained community.

Despite substantial developments in our knowledge and understanding of regenerative biology and stem cells, the field is in its infancy. The next few decades will unveil the true potential of this emerging specialty. Regenerative Medicine will provide a critical overview of these advances as they unfold and explore their potential relevance in the clinical setting.

The journal covers emerging strategies to replace or regenerate human cells, tissues or organs to restore or establish normal function, including:

- Bench-to-bedside translation and scale-up of stem cell and regenerative medicine therapies

- Potential applications for stem cell-based strategies in pathological conditions

- Stem cell pluripotency and emerging technologies

- Tissue engineering and artificial organ development

- Medical device and artificial organ development

- Regulatory and reimbursement issues

- Ethical and legal perspectives 


\section{Subscription options}

\section{Institutional subscriptions}

Regenerative Medicine is available in print, electronic or print and electronic formats, and pricing will depend on your organization type (academic, corporate, hospital, etc).Please contact info@futuremedicine.com for more details. Global e-access licenses are available on request and attract considerable discounts from standard site license fees. For further details on global access licenses, please contact Simon Boisseau: s.boisseau@futuremedicine.com

\section{Consortia pricing}

Regenerative Medicine welcomes discussion with all consortia, and offers flexible packages and discounted prices. If you have specific questions or would like a quote please contact info@futuremedicine.com for more details.

\section{Personal subscriptions}

Personal subscriptions are currently available to all Future Medicine journals. Payment must be made from a personal credit card registered to a home address. Print subscriptions will only be sent to a personal address. Please contact info@futuremedicine.com for our personal order form.

\section{Print subscription rates $(2012)$}

\begin{tabular}{|c|c|c|}
\hline Journal (6 issues) & $€$ Euro & US\$ \\
\hline Academic \& Hospital & 1035.00 & 1365.00 \\
\hline $\begin{array}{l}\text { Corporate, Government } \\
\text { \& NGO Centers }\end{array}$ & \multicolumn{2}{|c|}{$\begin{array}{l}\text { Please contact info@futuremedi- } \\
\text { cine.com for more details }\end{array}$} \\
\hline
\end{tabular}

\section{Ordering information}

Please contact your local sales representative to place an order:

\section{Worldwide}

Future Medicine Ltd

Unitec House, 2 Albert Place, London N3 IQB, UK

T: +44 (0)20 83433883

F: +44 (0)20 83432313

E: subscriptions@futuremedicine.com

\section{North America}

E: sales.us@futuremedicine.com

\section{Reprints}

Article reprints are available through our reprint service.

Please contact Sam Cavana: s.cavana@futuremedicine.com 
Future Medicine titles endorse the Uniform Requirements for Manuscripts Submitted to Biomedical Journals, issued by the International Committee for Medical Journal Editors, and Code of Conduct for Editors of Biomedical Journals, produced by the Committee on Publication Ethics.

This information is also available at www.futuremedicine.com

\section{Manuscript submission \& processing}

Future Medicine titles publish a range of article types, including solicited and unsolicited reviews, perspectives and original research articles. Receipt of all manuscripts will be acknowledged within 1 week and authors will be notified as to whether the article is to progress to external review. Initial screening of articles by internal editorial staff will assess the topicality and importance of the subject, the clarity of presentation, and relevance to the audience of the journal in question. If you are interested in submitting an article, or have any queries regarding article submission, please contact the Managing Commissioning Editor for the journal (contact information can be found on our website at: www.futuremedicine.com. For new article proposals, the Managing Commissioning Editor will require a brief article outline and working title in the first instance. We also have an active commissioning program whereby the Commissioning Editor, under the advice of the Editorial Advisory Panel, solicits articles directly for publication.

External peer review: Through a rigorous peer review process, Future Medicine titles aim to ensure that reviews are unbiased, scientifically accurate and clinically relevant. All articles are peer reviewed by three or more members of the International Advisory Board or other specialists selected on the basis of experience and expertise. Review is performed on a double-blind basis - the identities of peer reviewers and authors are kept confidential. Peer reviewers must disclose potential conflicts of interests that may affect their ability to provide an unbiased appraisal (see Conflict of Interest Policy below). Peer reviewers complete a referee report form, to provide general comments to the editor and both general and specific comments to the author(s).

Where an author believes that an editor has made an error in declining a paper, they may submit an appeal. The appeal letter should clearly state the reasons why the author(s) considers the decision to be incorrect and provide detailed, specific responses to any comments relating to the rejection of the review. Further advice from members of the journal's Editorial Advisory Panel external experts will be sought regarding eligibility for re-review.

Revision: Most manuscripts require some degree of revision prior to acceptance. Authors should provide two copies of the revised manuscript - one of which should be highlighted to show where changes have been made. Detailed responses to reviewers' comments, in a covering letter/email, are also required. Review manuscripts may be accepted at this point or may be subject to further peer review. The final decision on acceptability for publication lies with the journal editor.

\section{Post-acceptance}

Accepted review manuscripts are edited by the in-house Future Medicine editorial team Authors will receive proofs of their article for approval and sign off and will be asked to sign c transfer of copyright agreement, except in circumstances where the author is ineligible to do so (e.g. government employees in some countries).

\section{Author disclosure \& conflict of interest policy}

Authors must state explicitly whether potential conflicts do or do not exist (e.g. personal or financial relationships that could influence their actions) and any such potential conflict of interest (including sources of funding) should be summarized in a separate section of the published review. Authors must disclose whether they have received writing assistance and identify the sources of funding for such assistance. Authors declaring no conflict of interest are required to publish a statement to that effect within the article

Authors must certify that all affliations with or financial involvement with any organization or entity with a financial interest in or financial conflict with the subject matter or materials discussed in their manuscript have been disclosed. Please note that examples of financial involve ment include: employment, consultancies, honoraria, stock ownership or options, expert testimony, grants or patents received or pending and royalties. This is list is not exclusive of other forms of financial involvement. Details of relevant conflicts of interests (or the lack of) must be declared in the 'Disclosure' section of the manuscript for all listed authors.

External peer reviewers must disclose any conflicts of interest that could bias their opinions of the manuscript, and they should disqualify themselves from reviewing specific manuscripts if they believe it appropriate. Should any such conflict of interest be declared, the journal editor will judge whether the reviewer's comments should be recognized or will interpret the reviewer's comments in the context of any such declaration. 


\section{Authorship \& contributorship}

All authors should meet the ICMJE authorship criteria as follows: (1) they have provided significant input into the design and concept of the study that is the subject of the paper or were pivotal in the acquisition, analysis or interpretation of data: (2) they drafted the paper or were involved in making significant revisions; and (3) they aporoved the final version of the paper The corresponding author should accept direct responsibility for the manuscript, including liaising with all authors for their feedback and statements of disclosure, and will be responsible for approval of the final version prior to publication.

\section{Ethical conduct of research}

For studies involving data relating to human or animal experimental investigations, appropriate institutional review board approval is required and should be described within the article. For those investigators who do not have formal ethics review committees, the principles outlined in the Declaration of Helsinki should be followed. For investigations involving human subjects, authors should explain how informed consent was obtained from the participants involved.

\section{Patients' rights to privacy}

Patients have a right to privacy that should not be infringed without informed consent. Identify ing information should not be included unless the information is essential for scientifio purposes and the patient (or parent or legal guardian) gives written informed consent for publication Informed consent for this purpose requires that the patient be shown the manuscript to be published. When informed consent has been obtained it should be indicated in the manuscript. In attempting to maintain patient anonymity, identifying details should be omitted where they are not essential. However, patient data should never be amended or falsified Informed consent should be obtained whenever there is any doubt that anonymity can be assured

\section{Use of personal communications \& unpublished data}

Where an individual is identified within a review as a source of information in a personal com munication or as a source for unpublished data, authors should include a signed statement of permission from the individual(s) concerned and specify the date of communication.

\section{Clinical trial registration}

Future Medicine titles prefer to publish clinical trials that have been included in a clinica trials registry that is accessible to the public at no charge, is electronically searchable, is open to prospective registrants and is managed by a not-for-profit organization, such as www. clinicaltrials.gov (sponsored by the United States National Library of Medicine). Whilst referees will take registration status into account, all well designed and presented trials and corresponding data will be considered for publication.

\section{Errata/corrigenda}

Mistakes by either editor or author should be identified wherever possible and an erratum or corrigendum published at the earliest opportunity. We will attempt to contact the author of the original article to confirm any error, and publish an appropriate erratum or corrigendum at the earliest opportunity.

\section{Permissions for reproduced or adapted material}

Authors must acknowledge the origin of all text, figures, tables or other information that has been adapted or reproduced from other publications. Authors must provide a copy of the original source documents and should submit permission from the authors of the origina work and the original publishers for unlimited use in all markets and media (that includes both electronic and print use in any language).

\section{Duplicate publication/submission \& plagiarism}

All manuscripts submitted to Future Medicine titles are considered for publication on the understanding that they have not been published previously elsewhere or are under consideration for publication elsewhere. The journal may, however, consider republication of a paper previously published in a language other than English, subject to prominent disclosure of the original source and with any necessary permission. Authors will be asked to certify that the manuscript represents valid work and that neither this manuscript nor one with substantially similar content under their authorship has been published or is being considered for publication elsewhere, except as described in an attachment, and copies of closely related manuscripts are provided. The use of published or unpublished ideas, words or other intellectual property derived from other sources without attribution or permission, and representation of such as those of the author(s) is regarded as scientific misconduct and will be addressed as such.

\section{Misconduct}

If misconduct by authors or reviewers is suspected, either pre-or post-publication, action wil be taken. An explanation will be sought from the party or parties considered to be involved. If the response is unsatisfactory, then an appropriate authority will be asked to investigate fully. Future Medicine will make all reasonable attempts to obtain a resolution in any such eventuality and correct the record or archive as necessary 